\title{
Framework for land value capture from investments in transit in car-dependent cities
}

\author{
James Mclntosh \\ CUSP Institute, Western Australia \\ james.r.mcintosh@postgrad.curtin.edu.au \\ Roman Trubka \\ CUSP Institute, Western Australia \\ R.Trubka@curtin.edu.au
}

\author{
Peter Newman \\ CUSP Institute, Western Australia \\ p.newman@curtin.edu.au \\ Jeff Kenworthy \\ CUSP Institute, Western Australia \\ j.kenworthy@curtin.edu.au
}

\begin{abstract}
Many car-dependent cities have major transit projects stuck in financial and economic assessment due to inadequate links between land use, transport, and funding. This has left most urban transport networks underfunded and requiring significant government support. During this widening transit funding gap, there has been an international increase in demand on transit systems, which is in part a response to the global peak in car use per capita. This paper demonstrates to transit proponents and practitioners how to facilitate infrastructure projects by optimizing induced and activated land-use change.

A five-step framework for assessment is proposed that includes assessing the regional and local legislation and regulations to determine what alternative funding opportunities are available, undertaking accessibility beneficiary analysis, analyzing the project-induced land value uplift, developing an alternative funding strategy to implement integrated land-use and transport planning mechanisms, and preparing a procurement and delivery strategy. The proposed assessment framework enables transit business cases to extend project funding for integrated transit and land-use projects, especially in car-dependent cities. This is demonstrated through a case study of Perth, Western Australia.
\end{abstract}

Keywords: Land use, transit, accessibility, hedonic price modeling, value capture

\section{Introduction}

Internationally, funding for city and regional transit networks has traditionally been provided by governments from consolidated taxation revenue and market rate loans. There are, however, some exceptions; in the United States, for example, there is a history of hypothecating part or all of specific local and regional taxes to strategic transit funding, including the use of land value capture (Iacono et al.

Copyright 2015 James McIntosh, peter Newman, Roman Trubka, and Jeff Kenworthy

http://dx.doi.org/10.5198/jtlu.2015.531

ISSN: 1938-7849 | Licensed under the Creative Commons Attribution - Noncommercial License 3.0

The Journal of Transport and Land Use is the official journal of the World Society for Transport and Land Use (WSTLUR) and is published and sponsored by the University of Minnesota Center for Transportation Studies. This paper is also published with sponsorship from WSTLUR and the Institutes of Transportation Studies at the University of California, Davis, and the University of California, Berkeley. 
2009; US EPA 2013; Cervero 1997). A growing number of jurisdictions are seeing the value in strategic land-based "producer charge"-style levies, similar to other utilities and infrastructure (e.g., Hong Kong, the UK, United Sates, and Japan). However, there is no clear framework for the use of land value capture and other alternative funding methods. ${ }^{1}$

US cities have used versions of value capture for tax increment financing in particular, as well as for other funding mechanisms (Iacono et al. 2009), but there is no clear framework to enable a mainstreaming of this approach. In all other car-dependent areas internationally (such as Canadian, New Zealand, Australian, and even some European cities), there is no history of coordinated value capture assessment and implementation or indeed dedicated transit funding outside of relying on allocations of general tax revenue.

As transit has been mostly seen as a welfare item in state and regional governments' budgets (especially in car-dependent cities), new transit projects based wholly on general or consolidated revenue are often unable to be funded, due to the lack of a strategic fund or ongoing budget allocation, without the government exceeding lending limits. Though it has long been recognized that fixed transit infrastructure creates urban value in the property and land markets (Smith and Gihring 2006; Rodriguez and Targa 2004; Cervero and Kang 2010), there are few comprehensive assessment frameworks used to assess and capture the benefits that are created to assist this funding dilemma (Zhao and Larson 2011). At the same time, there is a need to integrate land use and transit systems to achieve a greater proportion of urban fabric that follows transit-oriented design (TOD) principles. When transit is funded only by traditional government funds, there is usually no incentive for providing TOD (Renne and Wells 2005), so such integrated transit and land use often just stays in the plans (Woodcock et al. 2010).

A new approach to funding urban transit infrastructure is needed in order to solve two problems simultaneously: creating a new funding source and assisting with the integration of TODs into any new transit project. This is especially important for car-dependent cities where there is a growing demand for transit with the peaking of car use (Newman et al. 2013; Goodwin 2012) and for TODs to support a transition toward more dense urban living (Newman et al. 2013).

This paper proposes a framework for assessing the transit accessibility and urban land market benefits created by investment in transit systems and a method for capturing these benefits to help defray the cost of transit investment. At the same time, it seeks to incentivize the provision of TODs. The gap in the published literature that this paper seeks to fill is in the development of an assessment framework for alternative funding options that are especially focused on capturing induced land and property market benefits for transit infrastructure projects in car-dependent cities. The framework is needed to help with funding and integrating land use. Such a framework could also be extended to cities with emerging economies in countries such as India that are also looking to expand their transit systems (Pucher et al. 2004).

\section{$2 \quad$ Background}

\subsection{Car dependence and the role of urban transit}

Newman and Kenworthy (1989) first coined the term "automobile dependence" in their book Cities and Automobile Dependence, which investigates 32 global cities while providing urban metrics for their analysis that include:

- Gasoline consumption,

- Public and private transport system modal split,

- Automobile infrastructure provision (road supply and parking) relative to transit, and

- A measure of urban density and of urban centralization.

1 "Value capture" is a term used to describe the process of capturing the induced land market financial benefits created by an investment that can then be used to aid in its funding. 
The traditionally automobile-dependent cities of North America and Australia are now investing substantially in the introduction and extension of urban transit systems (especially rail) in their cities to meet the demand for transit (Newman et al. 2013) and to reverse the issues created by the car dependence of their urban systems. Public transport, mass transportation, or urban transit cover the terms most commonly used for fixed route, fixed schedule urban passenger transit, covering modes such as bus, bus rapid transit (BRT), light-rail transit (LRT), heavy rail, and commuter rail (Vuchic 2005).

The focus of this paper is limited to fixed guideway services such as BRT and rail-based transit, as it is the permanence of the transit infrastructure of these systems that tends to produce an impact on the land and property markets (Yiu and Wong 2005; Debrezion et al. 2007; Mohammad et al. 2013). In addition to the operational differences between modes, fixed guideway transit is attractive to developers due to its permanence; it offers surety for long-term land development investment and hence is an attraction to live or work near (Cervero et al. 1993; Cervero 2004; Bartholomew and Ewing 2011). Integrated bus and transit projects can also widen the accessibility benefits in a corridor and create a larger transit accessibility zone than transit's traditional pedestrian catchment (Cervero 2004; Small and Verhoef 2007, p. 450-43; McIntosh et al. 2013).

\subsection{Urban transit infrastructure value creation in land and property markets}

The increased accessibility due to an investment in fixed transit infrastructure is monetized into its pedestrian catchment's land and property market values. This reflects a reduction in the generalized cost of travel, representing a "willingness to pay" (WTP) for a reduction in this economic cost (Batt 2001; Ewing and Cervero 2010). As indicated in Figure 1, this effectively moves the property closer to employment and other services in terms of time and up the bid rent curve (Alonso 1964; Muth 1969; O’Sullivan 2012).

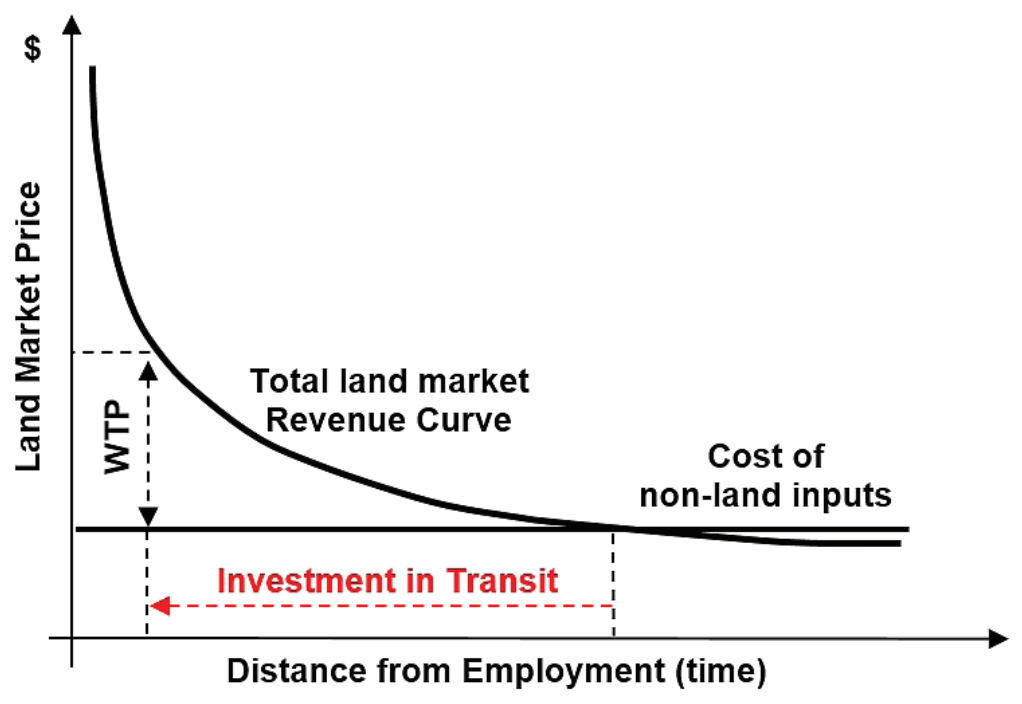

Figure 1: Land bid rent curve (Land Bid Rent = Total Revenue - Cost of non-land inputs) (Adapted from O'Sullivan 2012)

Although studies into the residential property market response to the investment in transit tend to agree that proximity and accessibility to urban transit delivers a value premium, the observed magnitude of the uplift can vary depending on a number of factors (Ewing and Cervero 2010). For one, these differences can be due to the assessment method used (different hedonic price modeling techniques, for example). Some studies state that the variances in the premium rate recorded can include the type of 
property and type of transit service and its level of accessibility when compared to a competitive mode of transport (such as a car) (Duncan 2008; Pan and Zhang 2008; Zhang 2010; Du and Mulley 2006; Debrezion et al. 2007; Mohammad et al. 2013). Variances in land value uplift can also be due to servicerelated operational issues such as noise, pollution, and crime levels in close proximity to the station (Diaz 1999; Hui and Ho 2004; PB 2001) as well as the transit station precinct's "density, diversity, and design" (Cervero 2004).

Mohammad et al. (2013) also noted a higher uplift premium due to transit in East Asian and European cities compared to North American and Australian cities. This is suggested as being due to high dependence on transit services in most of Europe and East Asia and high car dependence in North American and Australian cities. It could also relate partially to cultural norms, where living in higherdensity precincts is more common in the Asian and European context. This is a reason why in North American and Australian environments, the total "lifestyle package" offered by new transit-oriented developments needs to be excellent, reflected mainly in high-quality urban design of the public realm. Vancouver's sky train TODs are a good illustration that it is not transit "hardware" (steel-wheel trains or rubber-tire buses) that unlocks land-use changes but rather the quality of service and the comparative travel-time savings of transit versus the private car (Punter 2003). Table 1 presents a selection of the numerous studies into the differences in the observed impacts in land and property markets between bus and rail transit. 
Table 1: Authors' compilation of the transit-induced value uplift academic studies on the impact of differing types of transit on residential property and land market prices

\begin{tabular}{|c|c|c|c|c|c|}
\hline Author & Transit System & Value Measure & $\begin{array}{c}\text { Catchment } \\
\text { Area }\end{array}$ & Location & Premium Rate \\
\hline $\begin{array}{l}\text { TCRP } 90 \text { Vol. } 1 \\
\qquad(2003)\end{array}$ & $\begin{array}{l}\text { BRT (South East } \\
\text { Busway) }\end{array}$ & Property Value & Unspecified area & Brisbane, Australia & Up to $20 \%$ \\
\hline Mullins et al. (1990) & Transitway BRT & Property Value & Unspecified area & Ottawa, Canada & Limited \\
\hline $\begin{array}{l}\text { Rodriguez and Targa } \\
(2004)\end{array}$ & TransMilenio BRT & Rental Premium & $500 \mathrm{~m}$ & Bogota, Colombia & $6.8 \%$ to $9.3 \%$ \\
\hline $\begin{array}{c}\text { Rodriguez and Mojica } \\
(2008)\end{array}$ & Trans Milenio BRT & Rental Premium & $500 \mathrm{~m}$ & Bogota, Colombia & $13 \%$ to $15 \%$ \\
\hline $\begin{array}{c}\text { Perk and Catala, } \\
(2009)\end{array}$ & $\begin{array}{l}\text { BRT - Martin Luther } \\
\text { King, Jr. East Busway }\end{array}$ & Property value & $\begin{array}{l}\text { Distance mea- } \\
\text { sure from BRT }\end{array}$ & Pittsburgh, USA & $\begin{array}{c}\text { Significant and } \\
+\mathrm{ve} \\
\end{array}$ \\
\hline $\begin{array}{l}\text { Cervero and Kang } \\
\text { (2010) }\end{array}$ & Seoul BRT & Property value & \begin{tabular}{|c|}
$\begin{array}{c}90 \mathrm{~m} \text { to } 300 \mathrm{~m} \text { of } \\
\text { BRT stop }\end{array}$ \\
\end{tabular} & $\begin{array}{c}\text { Seoul, South } \\
\text { Korea }\end{array}$ & $5 \%$ to $10 \%$ \\
\hline $\begin{array}{c}\text { Al-Mosaind et al. } \\
\text { (1993) }\end{array}$ & MAX LRT & Property Value & $450 \mathrm{~m}$ & Portland, USA & $10.6 \%$ \\
\hline $\begin{array}{l}\text { Weinstein and Clower } \\
\text { (1999 \& 2002) }\end{array}$ & DART LRT & Property Value & $400 \mathrm{~m}$ & Dallas, USA & $\begin{array}{c}-5.2 \%(1999) \\
13 \% \text { to } 18 \% \\
(2002)\end{array}$ \\
\hline $\begin{array}{c}\text { Du and Mulley } \\
\text { (2007) }\end{array}$ & $\begin{array}{c}\text { Tyne and Wear } \\
\text { light rail }\end{array}$ & Property Value & & England, UK & $-42 \%$ to $50 \%$ \\
\hline Duncan (2008) & Light rail & Property Value & $400 \mathrm{~m}$ & San Diego, USA & $5.7 \%$ to $16.6 \%$ \\
\hline Landis (1995) & Santa Clara LRT & Property Value & $275 \mathrm{~m} \& 400 \mathrm{~m}$ & Santa Clara, USA & $10.8 \%$ to $45 \%$ \\
\hline Garrett (2004) & $\begin{array}{c}\text { St Louis Metrolink } \\
\text { LRT }\end{array}$ & Property Value & $30 \mathrm{~m}$ & Missouri, USA & $32 \%$ \\
\hline $\begin{array}{c}\text { Sedway Group (1999) } \\
\text { TCRP (2004) }\end{array}$ & $\begin{array}{l}\text { Bay Area Rapid } \\
\text { Transit (BART) }\end{array}$ & Rental Premium & $400 \mathrm{~m}$ & $\begin{array}{c}\text { San Francisco, } \\
\text { USA }\end{array}$ & $5 \%$ to $26 \%$ \\
\hline Wacher (1971) & $\begin{array}{l}\text { Metro, London } \\
\text { Victoria Line }\end{array}$ & Rental Premium & $400 \mathrm{~m}$ & London, UK & $1 \%$ to $5 \%$ \\
\hline Laakso (1992) & Helsinki Metro & Property Value & $400 \mathrm{~m}$ & Helsinki, Finland & $3.5 \%$ to $6 \%$ \\
\hline Bae et al. (2003) & Heavy Rail KoRail & Property Value & $400 \mathrm{~m}$ & $\begin{array}{c}\text { Seoul, South } \\
\text { Korea } \\
\end{array}$ & $0.3 \%$ to $2.6 \%$ \\
\hline $\begin{array}{c}\text { Yankaya and Celik } \\
(2004)\end{array}$ & Izmir Metro & Property Value & $400 \mathrm{~m}$ & Izmir, Turkey & $0.7 \%$ to $13.7 \%$ \\
\hline Gruen (1997) & $\begin{array}{c}\text { METRA, Commuter } \\
\text { Rail } \\
\end{array}$ & Property Value & $400 \mathrm{~m}$ & Chicago, USA & $20 \%$ \\
\hline Armstrong (1994) & $\begin{array}{c}\text { Boston Commuter } \\
\text { Rail } \\
\end{array}$ & Property Value & $400 \mathrm{~m}$ & Boston, USA & $6.7 \%$ \\
\hline Voith (1991) & Commuter Rail & Property Value & $400 \mathrm{~m}$ & Pennsylvania & \\
\hline \& New Jersey, USA & $3.8 \%$ to $10 \%$ & & & & \\
\hline
\end{tabular}

Therefore the key beneficiaries from transit infrastructure investment illustrated in Table 1 include:

- Land owners: due to increases in underlying land values.

- Property developers: potential increase in developed real estate values, faster sales rates, reduced holding costs, and lower construction costs due to reduced parking requirements.

- Transport system users: a more efficient, less congested transport system results in less time spent in transit, allowing more time for other activities and a better transit experience. 
- Business owners: increased economic activity due to improved customer and employee accessibility to their business, with workers arriving less stressed and more productive.

- Federal/state and local governments: due to increases in land-property-based revenue from existing levies and taxes from increased land and property values.

\subsection{Capturing the value created by the investment in transit}

The concept of capturing the value created by the investment in infrastructure (value capture) is not new internationally, with an early example being New York City in the United States, which implemented a special assessment district in 1691 to fund the construction of the city's drainage and street pavement program (Zhao and Larson 2011). Value capture mechanisms have been critical to investments in modern urban infrastructure in the United States in the early part of the twentieth century (Cervero 1994; Rybeck 2004). Now in the United States, all states use special assessment districts to finance both the construction and operation of urban infrastructure (American Public Works Association 2003). In 2008, special assessment districts and general value capture mechanisms comprised 0.26 percent of total state and local government revenue, with some state governments receiving more than 2 percent (including sewer, water, roads, and transit) (Zhao and Larson 2011).

Another long-term successful value capture program has been conducted by the Metropolitan Transit Railway Corporation (MRTC) in Hong Kong, which jointly develops its transit infrastructure with land development as part of the "Rail + Property" program (Cervero and Murakami 2009) by selling the development rights around and over its stations. By involving the private sector in land development around its stations, this program covers the cost of transit investments (Hui and Lo 2004; Zhao et al. 2009), thus making the strategic investment in transit a long-term cost-neutral decision for the government. However, strategic transport infrastructure rarely uses land-based beneficiary charging, with most car-dependent cities preferring usage charges such as tolls.

Unlike the United States, countries that do not have a legislative or regulatory history of direct land-based beneficiary levies and taxes can make transit infrastructure beneficiary capture significantly more challenging. The US system of transit funding is also rarely presented with a complete framework of options for integrated transit/land-use funding (Zhao and Larson 2011), thus requiring a new assessment and capture framework to be developed.

As shown previously, urban transit systems increase land value (McIntosh et al. 2011; Yiu and Wong 2005; Debrezion et al. 2007; Mohammad et al. 2013), and the process of value capture is the quantification of these induced or activated benefits and the mechanism for returning them to defray the cost of infrastructure investment (Allen 1987; Cervero 1997; Smith and Gihring 2009; Iacono et al. 2009; Cervero and Duncan 2002). Value capture provides a means to monetize a project's land and property market financial benefits as revenue that may either contribute (or be recognized and attributed) to infrastructure project costs. It also provides an understanding of the overall value created by a transit project, which allows:

- An understanding of the net cost of infrastructure,

- Development of options to offset the cost of the project,

- Support for cost-sharing arrangements between stakeholders,

- Support for long-term planning and integrated TOD policy development,

- Support for project affordability and funding analysis, and

- Development of a comprehensive project Value Proposition.

While this seems difficult, value capture is merely an approach consistent with sound economic and 
tax principles (Batt 2001). This captured value can be subsequently used to defray the capital cost of an infrastructure investment (Allen 1987; Center for Transit-Oriented Development 2008; Iacono et al. 2009, Zhao and Larson 2011) or to contribute to its operating costs (Smith and Gihring 2009; McIntosh et al. 2012).

Table 2 summarizes the value capture mechanisms available, whether they are related to government or non-government property, and whether the mechanisms passively generate revenue by impacting existing taxes and charges or require active intervention. 
Table 2: Compilation of value capture mechanism implementation from academic studies and operator and relevant government websites

\begin{tabular}{|c|c|c|c|}
\hline $\begin{array}{l}\text { Value Capture } \\
\text { Mechanisms }\end{array}$ & $\begin{array}{c}\text { Transit Project location (and } \\
\text { transit mode) }\end{array}$ & Author & Notes \\
\hline $\begin{array}{l}\text { Sale of surplus property /de- } \\
\text { velopment rights/air rights }\end{array}$ & $\begin{array}{l}\text { •Hong Kong, China (Metro) } \\
\text {-Washington DC, USA (Metro) } \\
\text { •Sydney, Australia (Heavy Rail) }\end{array}$ & $\begin{array}{l}\cdot \text { MTRC } \\
\cdot \text { WMATA } \\
\text {-RailCorp } \\
\end{array}$ & \multirow{2}{*}{$\begin{array}{c}\text { Used when governments } \\
\text { hold their property and } \\
\text { receive a benefit when ac- } \\
\text { cessibility is monetized into } \\
\text { their property values }\end{array}$} \\
\hline $\begin{array}{l}\text { Sale of stations' naming } \\
\text { rights }\end{array}$ & $\begin{array}{l}\text { New York, USA } \\
\text { •Philadelphia, USA } \\
\end{array}$ & $\begin{array}{l}\text {-MTA } \\
\bullet \text { SEPTA } \\
\end{array}$ & \\
\hline $\begin{array}{l}\text { Direct development of } \\
\text { government property }\end{array}$ & •Hong Kong, China (Metro) & •MTRC & \multirow{5}{*}{$\begin{array}{l}\text { Mechanisms to capture } \\
\text { increases in land values and } \\
\text { economic prosperity that } \\
\text { positively impact the value } \\
\text { of state and local govern- } \\
\text { ment property and land } \\
\text { from transit }\end{array}$} \\
\hline Joint development & $\begin{array}{l}\text {-Tokyo, Japan (Metro) } \\
\text { •Hong Kong, China (Metro) } \\
\text { •London, UK (Metro) }\end{array}$ & $\begin{array}{l}\cdot \text { Tokyo Metro } \\
\bullet \text { MTRC } \\
\bullet \text { Crossrail Stns.- Canary } \\
\text { Wharf \& Heathrow Airport }\end{array}$ & \\
\hline $\begin{array}{l}\text { Returns on government } \\
\text { parking }\end{array}$ & -Portland, USA (Streetcar/LRT) & -Portland Streetcar & \\
\hline $\begin{array}{l}\text { Government property } \\
\text { leasing }\end{array}$ & -Philadelphia (USA) & •SEPTA & \\
\hline Advertising revenue & \multicolumn{2}{|l|}{ International implementation } & \\
\hline TIF \& hypothecated taxes & & & \multirow{4}{*}{$\begin{array}{c}\text { Primarily focused on } \\
\text { increases in existing ad } \\
\text { valorem taxes that result } \\
\text { from increases in property } \\
\text { and land value }\end{array}$} \\
\hline $\begin{array}{l}\text { State transfer duty/sales } \\
\text { taxes }\end{array}$ & $\begin{array}{l}\text {-Atlanta, USA (Heavy Rail) } \\
\text { •Dallas, USA (LRT) } \\
\end{array}$ & \begin{tabular}{|l|}
-MARTA \\
-DART \\
\end{tabular} & \\
\hline State land/property tax & \begin{tabular}{|l|}
-Dallas, USA (LRT) \\
•Portland, USA (Streetcar/LRT)
\end{tabular} & \begin{tabular}{|l|} 
- DART \\
-Portland Streetcar \\
\end{tabular} & \\
\hline $\begin{array}{l}\text { Local government rates/ } \\
\text { taxes }\end{array}$ & -Portland, USA (Streetcar/LRT) & -Portland Streetcar & \\
\hline $\begin{array}{l}\text { Benefit area levies (or Spe- } \\
\text { cial Assessment Districts) } \\
\text { through state or local } \\
\text { government infrastructure } \\
\text { cost recovery }\end{array}$ & $\begin{array}{l}\text {-London, UK (Metro) } \\
\text { •Seattle, USA (Streetcar/LRT) } \\
\text { •Portland, USA (Streetcar/LRT) }\end{array}$ & $\begin{array}{l}\text {-Crossrail Business Rate } \\
\text { Supplement } \\
\text {-Seattle Streetcar } \\
\text {-Portland Streetcar }\end{array}$ & \multirow{8}{*}{$\begin{array}{l}\text { Mechanisms to capture all } \\
\text { or part of the increases in } \\
\text { property and land values } \\
\text { and economic prosperity } \\
\text { that benefit non-govern- } \\
\text { ment land and business } \\
\text { owners }\end{array}$} \\
\hline $\begin{array}{l}\text { Differential rates, specified } \\
\text { area rates, service charges }\end{array}$ & $\begin{array}{l}\text { •Atlanta, USA (Heavy Rail) } \\
\text {-Dallas, USA (LRT) }\end{array}$ & $\begin{array}{l}\text { MARTA } \\
\text { •DART } \\
\end{array}$ & \\
\hline Region wide transport levy & - Portland, USA (Streetcar/LRT) & -Portland Streetcar & \\
\hline $\begin{array}{l}\text { Existing Infrastructure Tax } \\
\text { Hypothecation }\end{array}$ & $\begin{array}{l}\text { London, UK (Metro) } \\
\text { •Portland, USA (Streetcar/LRT) }\end{array}$ & $\begin{array}{l}\cdot \text { Crossrail Community } \\
\text { Infrastructure Levy } \\
\text { •Portland Streetcar }\end{array}$ & \\
\hline Developer contributions & \multirow{2}{*}{\multicolumn{2}{|c|}{ International implementation }} & \\
\hline Parking levies/bonds & & & \\
\hline $\begin{array}{l}\text { Development Parking lev- } \\
\text { ies, increased cash in lieu, } \\
\text { metropolitan-wide parking } \\
\text { levy }\end{array}$ & $\begin{array}{l}\text {-Portland, USA (Streetcar/LRT) } \\
\text {-San Francisco, USA }\end{array}$ & $\begin{array}{l}\text {-Portland Streetcar Inc. } \\
\text {-SFMTA }\end{array}$ & \\
\hline Density bonuses & $\begin{array}{l}\text { •New York, USA (metro) } \\
\text { •Curitiba, Brazil }\end{array}$ & $\begin{array}{l}\bullet \text { NYC Department of Plan- } \\
\text { ning } \\
\text { •Rede Integrada de Trans- } \\
\text { porte }\end{array}$ & \\
\hline
\end{tabular}


The examples in Table 2 demonstrate the range of international implementation of the different value capture and alternative funding mechanisms available. The disparate nature of their implementation illustrates the difficulty in assigning one particular mechanism to a single project in one jurisdiction. The value capture framework proposed addresses these regional differences in an assessment methodology for international implementation.

\section{Framework for capturing value of transit in car-dependent cities}

The key strategic objective of the investment in transit in car-dependent cities is to seek to address car dependence in the transport and land-use systems in the most economically and financially efficient and effective way for as many people in the city as possible. This paper proposes a conceptual framework for the integration of strategic land-use, transport, and funding/financial planning analysis. This culminates in a value capture strategy to integrate all of a transit project's transport, land-use/development, and funding/financial components to optimize the project's integration benefits and thus enable implementation. To achieve this objective, the proposed steps in the integrated land-use, transport, and funding assessment framework are:

Step 1. Assessment of the relevant alternative funding legislation and regulations

Step 2. Accessibility beneficiary analysis

Step 3. Land and property market analysis of "willingness to pay" for transit accessibility

Step 4. Analysis of the transit project value capture mechanisms and preparation of the integrated land-use and transit project value proposition

Step 5. Procurement and implementation strategy through hypothecated transit fund

The integrated framework and each of its assessment steps and their interactions is conceptually illustrated in Figure 2.

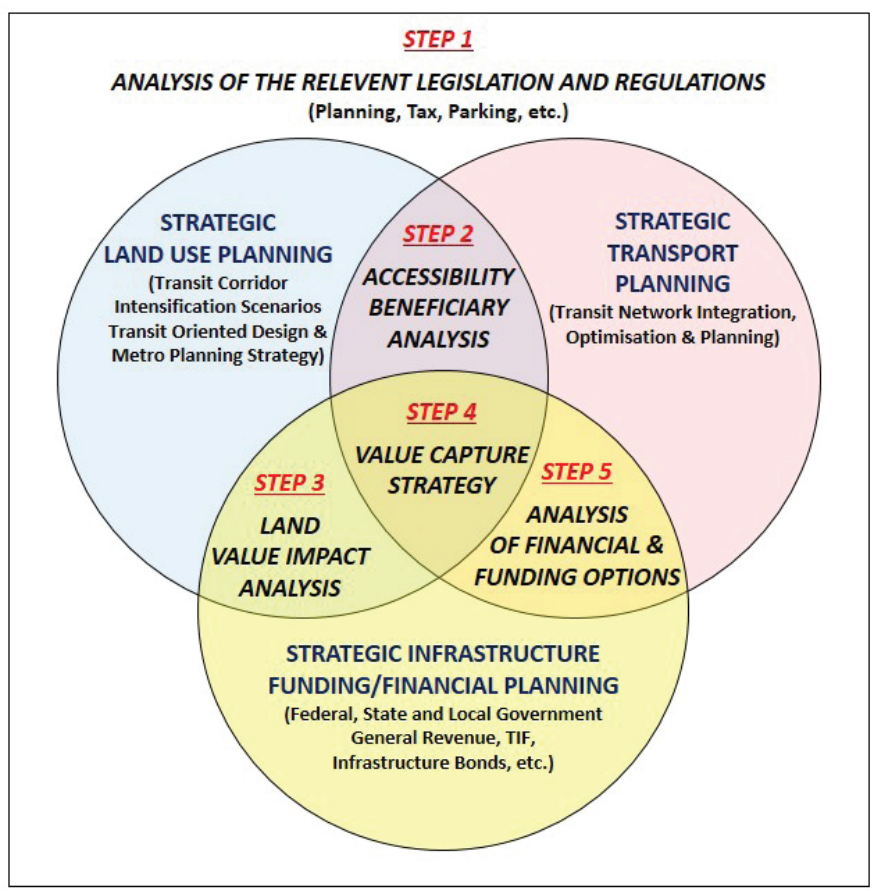

Figure 2: Conceptual value capture analysis framework for the integration of strategic transit land use, transport and funding/ financial planning 


\subsection{Step 1: Assessment of the relevant alternative funding legislation and regulations}

The first step in the integrated assessment methodology is to conduct a legislative review of the region's relevant government legislation and regulations, including:

- Planning and development legislation (related to the ability to facilitate redevelopment),

- Taxation legislation (state and federal government) and local government rates, and

- Parking regulations and legislation.

This stage is an important step in the methodology to ascertain what existing legislative opportunities are available, and it forms the regulatory basis for the value capture and alternative funding strategy. If there is a regulatory or legislative deficiency that would inhibit the introduction of the value capture framework, new or altered legislation and regulations would be proposed, such as the introduction of Tax Increment Financing (TIF) legislation.

\subsection{Step 2: Accessibility beneficiary analysis}

Transport network accessibility is a critical aspect of metropolitan spatial and economic structures (Guiliano et al. 2010), and the role of transit accessibility is vital for cities to overcome car dependence (Newman and Kenworthy 1999). Understanding the nature of the change in transit generated by a transport investment is vital in determining the distribution and size of the transport accessibility benefits that are delivered to the property and land market catchments. There are a number of transit accessibility metrics available, including SNAMUTS (Scheurer 2010) and AAM (Espada 2010), but simpler methods such as calculating pedestrian catchments using a GIS system can also be employed.

\subsection{Step 3: Land and property market analysis of the willingness to pay for transit accessibility}

The integration of the land and transport markets is one of the key drivers of the value capture framework, with the optimum value uplift and capture opportunities occurring where both objectives are combined. While the level of value uplift in the land and property markets can differ depending on the nature of the project, the significance of all the land market factors can be determined by undertaking hedonic price analysis of the land values of commercial, industrial, and residential properties (Small and Verhoef 2007). In the meta-analysis of different studies into the impact of rail on land and property values, Mohammad et al. (2013) discuss the use of a range of estimation methods to determine the impact of the investment in rail transit on property and land prices, which include the following (with selected articles to refer):

- Hedonic price modeling (cross section, panel data, time series) (Al-Mosaind et al. 1993)

- Geographically weighted regression (Du and Mulley 2006)

- Average property/land value comparison (Sherry 1999; National Association of Realtors 2013)

- Direct differencing of land values (Fejarang 1994)

While dependent on data availability, the use of time variant panel data hedonic price modeling is likely to be the most effective for illustrating the impact of transit investment as it changes over different stages of its planning, construction, and operation (Agostini and Palmucci 2008; Bae et al. 2003; Mohammad et al. 2013). If there is insufficient data, or a lack of a comparable investment that has been implemented within a similar region, cross-sectional analysis can demonstrate the value premium that the property 
and land markets place on in situ infrastructure (Al-Mosaind et al. 1993; Du and Mulley 2007; Laakso 1992; Voith 1991). The estimation of the price premium in property and land markets forms the basis for the alternative funding framework, and it is critical for communicating the benefits to stakeholders.

\subsection{Step 4: Analysis of the transit project value capture mechanisms available}

Based on the outcomes from Step 1 of the framework, an analysis of the different value capture mechanisms available to a transit project can be undertaken. There are many different types of value capture mechanisms (including both strategic and project-focused mechanisms). Table 3 proposes a value capture framework to assess and capture the value created by transit projects.

Table 3: Value capture framework (adapted from McIntosh et al. 2011)

\begin{tabular}{|c|c|c|c|c|c|c|}
\hline $\begin{array}{c}\text { Property VC } \\
\text { Form }\end{array}$ & Value Created & $\begin{array}{l}\text { Location/ } \\
\text { Region }\end{array}$ & $\begin{array}{c}\text { Project } \\
\text { Beneficiary }\end{array}$ & $\begin{array}{c}\text { Assessment } \\
\text { Methodology }\end{array}$ & VC Mechanism & $\begin{array}{c}\text { Financial } \\
\text { Return }\end{array}$ \\
\hline $\begin{array}{l}\text { Government } \\
\text { Property } \\
\text { (Passive) }\end{array}$ & $\begin{array}{l}\text { Increased } \\
\text { value of Govt. } \\
\text { property }\end{array}$ & $\begin{array}{l}\text { Transit regional } \\
\text { beneficiary } \\
\text { catchment }\end{array}$ & $\begin{array}{l}\text { Govt. land } \\
\text { owners within } \\
\text { the catchment }\end{array}$ & $\begin{array}{l}\text { Value of prop- } \\
\text { erty with and } \\
\text { without project }\end{array}$ & $\begin{array}{l}\text {-Sale of surplus property } \\
\text { - Hold property }\end{array}$ & $\begin{array}{l}\text { Increase in } \\
\text { future sale } \\
\text { price }\end{array}$ \\
\hline $\begin{array}{l}\text { Government } \\
\text { Property } \\
\text { (Active) }\end{array}$ & $\begin{array}{l}\text { Govt. property } \\
\text { development }\end{array}$ & $\begin{array}{l}\text { Stations along } \\
\text { the alignment }\end{array}$ & $\begin{array}{l}\text { Govt. land } \\
\text { owners within } \\
\text { the catchment } \\
\text { \& developers }\end{array}$ & $\begin{array}{l}\text { Property devel- } \\
\text { opment analysis }\end{array}$ & $\begin{array}{l}\text {-Property development } \\
\text {-Parking returns } \\
\text {-Rental returns } \\
\text {-Joint development } \\
\text {-Advertising }\end{array}$ & $\begin{array}{l}\text { Development } \\
\text { returns, rental } \\
\text { returns, etc. }\end{array}$ \\
\hline $\begin{array}{l}\text { Non-Govern- } \\
\text { ment Property } \\
\text { (Passive) }\end{array}$ & $\begin{array}{l}\text { Increased value } \\
\text { of non-Govt. } \\
\text { property }\end{array}$ & $\begin{array}{l}\text { Transit regional } \\
\text { beneficiary } \\
\text { catchment }\end{array}$ & $\begin{array}{l}\text { Private land } \\
\text { owners within } \\
\text { the catchment }\end{array}$ & $\begin{array}{l}\text { Hedonic price } \\
\text { modeling }\end{array}$ & $\begin{array}{l}\text {-Increase in existing ad } \\
\text { valorem taxes }\end{array}$ & $\begin{array}{l}\text { Increase in } \\
\text { earnings from } \\
\text { current tax } \\
\text { regimes }\end{array}$ \\
\hline $\begin{array}{l}\text { Non-Govern- } \\
\text { ment Property } \\
\text { (Active) }\end{array}$ & $\begin{array}{l}\text { Increased value } \\
\text { of non-Govt. } \\
\text { property }\end{array}$ & $\begin{array}{l}\text { Stations along } \\
\text { the alignment }\end{array}$ & $\begin{array}{l}\text { Private land } \\
\text { owners within } \\
\text { the catchment } \\
\& \text { developers }\end{array}$ & $\begin{array}{l}\text { Hedonic price } \\
\text { modeling \& } \\
\text { property devel- } \\
\text { opment analysis }\end{array}$ & $\begin{array}{l}\text {-Benefit area levies, spe- } \\
\text { cial assessment districts } \\
\text {-Developer levies/fees } \\
\text { •Changes in duties and } \\
\text { taxes } \\
\text {-In-kind developer } \\
\text { contributions }\end{array}$ & $\begin{array}{l}\text { Increase in } \\
\text { earnings } \\
\text { from new tax } \\
\text { regimes }\end{array}$ \\
\hline
\end{tabular}

Prior to the implementation of the value capture mechanisms into a transit project's Value Proposition, each mechanism should be evaluated against a policy evaluation framework (such as the one presented in Table 4). Externalities from poorly implemented funding mechanisms arise where there are divergences between social and private costs and are an example of a circumstance where the market acting alone will deliver poor outcomes (Allen Consulting Group 2003). Funding options that allow the full economic, social, and environmental costs to be accurately reflected in prices will, in general, be those that least distort economic activity and lead to the best community outcomes (Allen Consulting Group 2003; TCRP 2009; Litman 2013). 
Table 4: Value capture mechanism evaluation criteria (Center for Transportation Studies 2009; Allen Consulting Group 2003; TCRP Report 129 2009)

\begin{tabular}{|c|c|}
\hline $\begin{array}{l}\text { Evaluation } \\
\text { Criteria }\end{array}$ & Explanatory Notes \\
\hline Revenue Yield & $\begin{array}{l}\text { Whether the mechanism generates adequate yield for the cost of implementation and if the mecha- } \\
\text { nism is stable over time. }\end{array}$ \\
\hline Cost Effectiveness & $\begin{array}{l}\text { Effectiveness is the central requirement of a funding approach to mobilize sufficient funds for invest- } \\
\text { ment in infrastructure and to do so in a timely manner. }\end{array}$ \\
\hline $\begin{array}{l}\text { Economic } \\
\text { Efficiency }\end{array}$ & $\begin{array}{l}\text { Allocative efficiency is a longstanding concern of governments, and measures that distort economic } \\
\text { decision making with regard to investment or consumption patterns can lead to outcomes that shrink } \\
\text { overall well-being. }\end{array}$ \\
\hline Equity & $\begin{array}{l}\text { Social justice concerns about sharing the burden of revenue raising fairly between individuals who } \\
\text { have differing abilities to pay: it is generally deemed fair if people in similar economic circumstances } \\
\text { are treated similarly (horizontal equity) and the amount paid varies in relation to the individual's } \\
\text { economic circumstances (vertical equity). }\end{array}$ \\
\hline $\begin{array}{l}\text { Compliance Costs, } \\
\text { Certainty, \& } \\
\text { Transparency } \\
\end{array}$ & $\begin{array}{l}\text { Low compliance costs and certainty are crucial in effective planning for businesses, with transparency } \\
\text { being a key means of reducing uncertainty as it facilitates an understanding of the process and issues } \\
\text { that need to be dealt with. }\end{array}$ \\
\hline $\begin{array}{l}\text { Stakeholder } \\
\text { Support }\end{array}$ & $\begin{array}{l}\text { Ultimately, every funding approach requires making someone pay, and governments are well aware } \\
\text { that this inevitably involves discontent from some quarter in the community. However, this does not } \\
\text { automatically preclude widespread support for a measure, with the question of support often more } \\
\text { about reasonableness and the outcome of a fair process or trust in a fair decision maker and a "level } \\
\text { playing field." The perception of fairness on the part of the development community is critical. Any } \\
\text { suggestion that one group or project can avoid such costs while another has to pay will be rejected. }\end{array}$ \\
\hline $\begin{array}{l}\text { Technical } \\
\text { Feasibility }\end{array}$ & $\begin{array}{l}\text { New technology is used in the collection of transport-related taxes and revenue handling, and while } \\
\text { these can be effective and accurate in allocation and collection of costs, they can add another layer of } \\
\text { complexity to traditional methods of funding collection. }\end{array}$ \\
\hline
\end{tabular}

The preparation of a transit project value capture mechanism assessment matrix (Table 5) acts as a cash flow statement that summarizes the net financial revenues for each tier of government in a transit project as well as assessing the economic impacts of each of the proposed mechanisms. 
Table 5: Project value capture mechanism financial and economic analysis matrix

\begin{tabular}{|c|c|c|c|c|c|c|c|c|c|c|c|c|}
\hline & \multicolumn{5}{|c|}{$\begin{array}{l}\text { Revenue Yield (NPV \$) \& as a \% } \\
\text { of Project Cost }\end{array}$} & \multicolumn{7}{|c|}{ Qualitative Indicators (Evaluation Criteria -3 to 3) } \\
\hline & 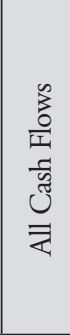 & 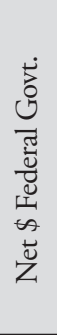 & 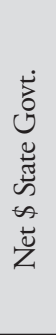 & 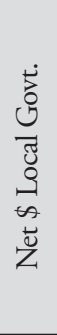 & 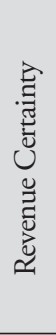 & 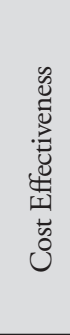 & 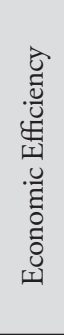 & 急 & 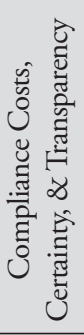 & 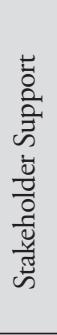 & 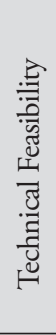 & 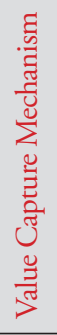 \\
\hline $\begin{array}{l}\text { Government Property } \\
\text { (Passive Mechanisms) }\end{array}$ & & & & & & & & & & & & \\
\hline $\begin{array}{l}\text { Government Property } \\
\text { (Active Mechanisms) }\end{array}$ & & & & & & & & & & & & \\
\hline $\begin{array}{l}\text { Non-Government Property } \\
\text { (Passive Mechanisms) }\end{array}$ & & & & & & & & & & & & \\
\hline $\begin{array}{l}\text { Non-Government Property } \\
\text { (Active Mechanisms) }\end{array}$ & & & & & & & & & & & & \\
\hline Total Value Capture Revenue & & & & & & & & & & & & \\
\hline
\end{tabular}

Each tier of government has demands on their limited resources, and the project's value capture mechanism analysis matrix (as presented in Table 5) importantly demonstrates the funding contributions required as they relate to their financial return. This illustration of project cash flow forms a critical component of the intergovernmental and community negotiations regarding the levels of project contribution from each party, since it enables each to weigh their level of contribution to the benefit they will receive.

\subsection{Step 5: Establish a procurement strategy through an hypothecated transit fund and implementation strategy}

The strategic funding for an urban transit network extends beyond the local area directly impacted by a particular project, since it will provide accessibility impacts for the greater region. Thus a strategic value capture fund into which value capture financing can be directed should be established at a metropolitan region level. The fund's hypothecated revenue stream would enable strategic funding of the transit network and could be used to directly:

- Repay transport infrastructure bonds,

- Contribute to private-sector-financed infrastructure availability payments, or

- Repay the directly incurred project infrastructure debt.

An important revenue stream for strategically funding transit is to collect passive tax increases related to property value uplift and use it as a basis for project financing, which is a process called tax increment financing (TIF) (Sullivan et al. 2002; Zhao and Larson 2011). TIF is simply the term used by governments (especially in the United States) for the way in which a debt-financing facility is created against a secure revenue source (such as the transit fund proposed) utilizing future taxes or levy revenue to repay debt incurred to finance public infrastructure (Allen Consulting Group 2003). 
Broad value capture TIFs could work by recognizing and securitizing the additional funds in the value capture framework from the induced increases in the existing tax base (e.g., stamp duty, land tax, etc.) or more actively from new taxes or levies, and these levies can be collected and securitized to raise finances that can help defray capital and operating costs of an infrastructure project. The infrastructure debt would be repaid over time by the transit fund using the hypothecated incremental tax cash flow. This passive increase in government property taxes will be received as long as the increased value in transit amenity continues to be monetized into land and property markets.

An implementation strategy could then be based on a completely public approach, a mostly private-sector approach, or a mixture of the two. Innovative technologies and approaches to building around stations and operating the system all become feasible with the use of the transit fund providing an ongoing source for financing all aspects of the transit system.

\section{Case study: Transit value capturing in a car-dependent city, Perth, Western Australia}

Perth is the capital city of the state of Western Australia with a current population of 1.81 million people, making it the fourth most populous city in Australia and the most rapidly growing (Australian Bureau of Statistics 2013). The Global Cities Database for 1995 (Kenworthy and Laube 1999) shows Perth had the tenth highest total private passenger vehicle kilometers traveled (VKT) per capita of the cities reported (the first of the 84 cities outside of the United States) and the lowest transit mode share in Australia.

Metropolitan Perth has had rail transit since the late nineteenth century and increased its distribution in the late twentieth and early twenty-first centuries under considerable political and community pressure. This is particularly evident in the provision of the Joondalup and Mandurah rail lines, which commenced operating in 1996 and 2007 respectively and were built deeply into Perth's car-dependent suburbs down freeway medians. These lines have been very successful, against the predictions of many transport planners, since they were going into unexplored territory in terms of the usual land use associated with transit (McIntosh et al. 2013). This case study will investigate the value capture opportunities that could have been captured to fund the introduction of the Mandurah Line in 2007.

\subsection{Step 1: Assessment of the relevant alternative funding legislation and regulations}

A review of Western Australian government legislation and policies identified that in addition to the existing land value capture legislative mechanisms, there is legislation that has mechanisms that can facilitate alternative funding sources for transit infrastructure. There are four main existing legislative acts enabling value capture funding:

- Planning and Development Act, 2005

- Land Tax Act, 2002

- Perth Parking Management Act, 1999

- Local Government Act, 1995

These mechanisms were not initially planned to enable value capture, but without any changes they can be adapted for this purpose (McIntosh et al. 2011). The presence of legislation that enables alternative funding mechanisms is important in the process to facilitate value capture implementation, though it is unlikely that all jurisdictions have all the mechanisms required to assemble land, capture land value taxes, and hypothecate these revenues into a coordinated fund. Most cities, however, will have some of the necessary legislative base. 


\subsection{Step 2: Accessibility beneficiary analysis}

Public transport accessibility assessments were conducted for Perth using both SNAMUTS (Scheurer 2011) and AAM (Espada 2011; Espada and Luk 2011), and the results are presented in Figure 3. While the two measures use different accessibility assessment methods and are presented at differing scales, as one might expect they both report similar results with accessibility highest in the central areas. The implications of these analyses are that the higher the level of transit accessibility provided to the benefiting land catchments, the higher the level of benefit perceived, and subsequently the greater the level of "willingness to pay" for transit accessibility. For the purposes of this research only, the SNAMUTS model was used.

\subsubsection{Spatial Network Analysis for Multimodal Urban Transport Systems (SNAMUTS)}

Spatial Network Analysis for Multimodal Urban Transport Systems (SNAMUTS) is a GIS-based tool that assesses the relationship between transit network configuration, performance and service standards, and the geographical distribution of clustering of land-use activities across a metropolitan area (Scheurer 2010).

SNAMUTS is based on a supply-side analysis of land use-transport interaction and has been designed to facilitate decision making about transit service and infrastructure improvements as well as the location of land-use intensification measures. The greatest value of the use of SNAMUTS is the delineation of the accessibility impact of discrete transit projects, as well as land development projects on their localized neighborhood. In addition to this, it also highlights the variation in public transit accessibility across the metropolitan region's transit network as a whole. 

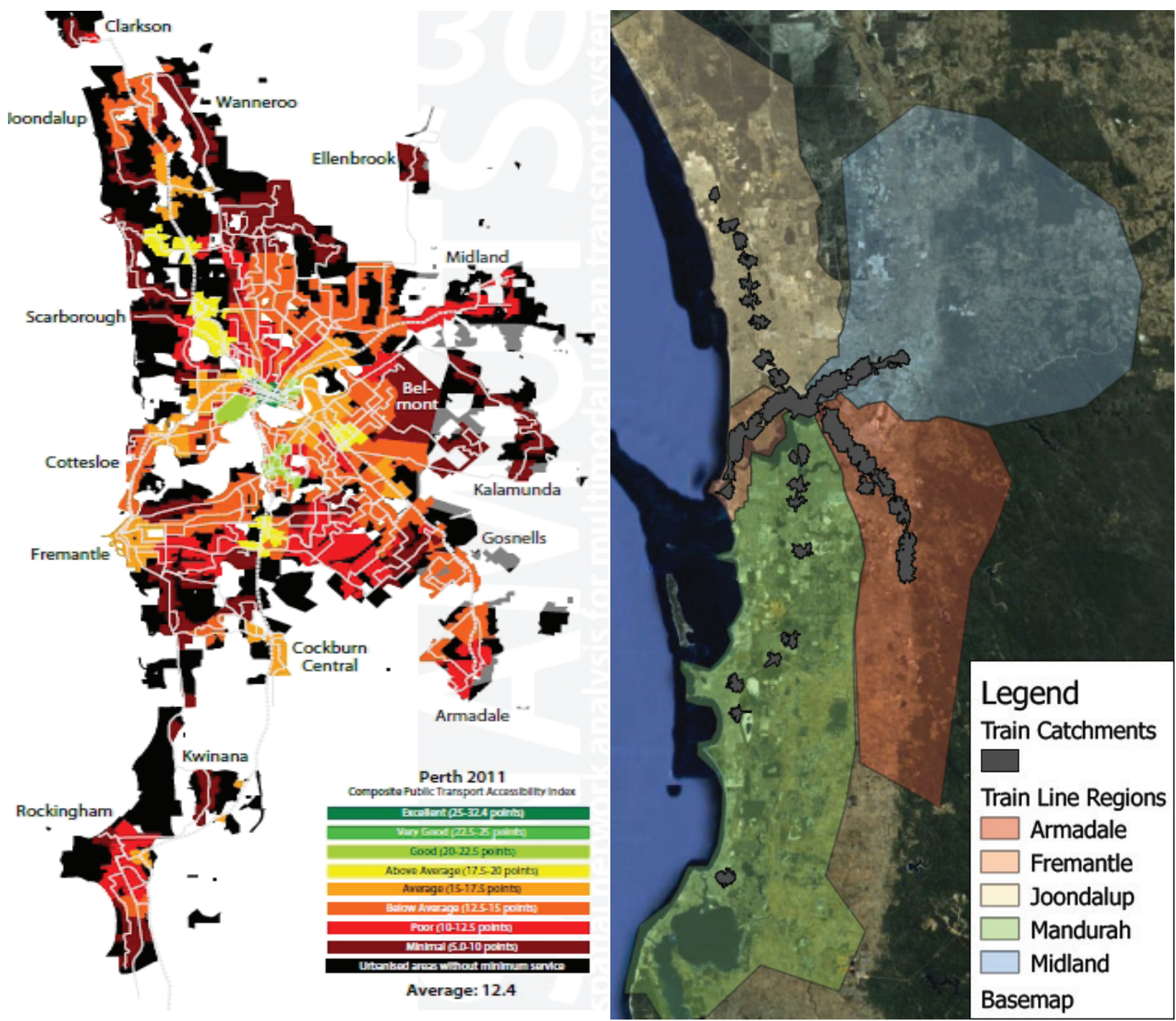

Figure 3: SNAMUTS public transit accessibility model for Perth, 2011 (Scheurer 2011) (left), Perth rail pedestrian catchments (right)

\subsection{Step 3: Land value impact analysis}

A panel data hedonic pricing model (HPM) was developed for the rail transit catchments in metropolitan Perth (shown in Figure 3) in order to predict the impact in property values from rail infrastructure over time - in particular over the time period of the introduction of the Mandurah rail line. Land value per square meter was modeled for 462,476 residential land parcels across metropolitan Perth (see the descriptive statistics in Table 6). The residential land models included $400 \mathrm{~m}, 800 \mathrm{~m}$, and $1600 \mathrm{~m}$ proximity bands to rail stations (road network service areas), and they reflect the 5-, 10-, and 20-minute rail station pedestrian catchments. The models also included SNAMUTS indicator values to control for transit network level-of-service and to capture the accessibility benefits outside the rail catchments that are generated by feeder-bus services and the rest of the general bus network. Table 6 presents a full set of descriptive statistics for the HPM.

In the Log-Log functional form of the estimated hedonic models, the parameter estimates for the 
continuous variables are interpreted as elasticities (i.e., the percentage change in land value due to a 1 percent change in a continuous explanatory variable while those for dichotomous variables or dummy variables) are interpreted as uplift percentages (i.e., the percentage change in land value due to a unit change in a dichotomous explanatory variable).

The dichotomous variables included the three train station catchment dummies and the two highway proximity bands, while the rest of the variables in the residential and commercial models were continuous. The majority of the control variables in the models were of expected sign and magnitude, and importantly the evidence of land value uplift as a result of proximity to rail was very compelling (and consistent with the data compiled in Table 1). These uplift values are relative to all properties further than 1600 meters from a train station, which is considered to be well beyond the acceptable pedestrian accessibility to transit (further than a 20 minute walk). The individual train line models reveal interesting trends relating to how passenger rail access impacts land values to a different extent in different regions.

Panel data modeling of the temporal variation in land prices is important for understanding the behavior of land prices over time. Many of the cross-sectional variables are non-stationary in a temporal sense and can reflect a number of factors, such as:

- Economic changes,

- Technology changes,

- Political shifts, and

- Cultural movements (gentrification, etc.).

In addition to these factors, a panel data HPM was estimated in order to validate theories of how accessibility benefits are monetized into land values prior to and during construction as well as after the commencement of operations of a rail line. The panel data modeling method employed time dummies as well as pooled data time variant terms with the rail line pedestrian catchments over the period 2001 to 2011. The annual datasets were then stacked to form a single complete panel dataset containing all the residential land valuations over the 11-year period. 
Table 6: Descriptive statistics for the residential HPM for 2011: Fremantle (1), Armadale (2), Midland (3), Mandurah (4), and Joondalup (5)

\begin{tabular}{|c|c|c|c|c|c|c|}
\hline \multirow[t]{2}{*}{ Explanatory Variables } & \multicolumn{6}{|c|}{ Mean or Percentage Values } \\
\hline & All Regions & (1) & (2) & (3) & (4) & (5) \\
\hline Land Value $/ \mathrm{m}^{2}$ (no view) (AUD\$ 2011) & 590.69 & 1646.59 & 366.95 & 425.29 & 542.88 & 632.00 \\
\hline Log Land Value/m² (no view) (AUD\$ 2011) & 6.121 & 7.306 & 5.692 & 5.714 & 6.103 & 6.336 \\
\hline Number of Land Parcels & 462,476 & 28,487 & 85,108 & 67,761 & 128,136 & 152,974 \\
\hline \multicolumn{7}{|l|}{ Transportation Proximity } \\
\hline \multicolumn{7}{|l|}{$400 \mathrm{~m}$ train catchment } \\
\hline number of parcels & 5300 & 1913 & 1401 & 1440 & 224 & 321 \\
\hline ( $\%$ of total catchment number of parcels) & $(1.2 \%)$ & $(6.7 \%)$ & $(1.6 \%)$ & $(2.1 \%)$ & $(0.2 \%)$ & $(0.2 \%)$ \\
\hline [Ave. Catch. LandVal./m² AUD\$ 2011] & {$[1044.03]$} & {$[1885.62]$} & {$[473.19]$} & {$[701.85]$} & {$[325.27]$} & [556.69] \\
\hline$\{$ Ave. Catch. Log LandVal./m² AUD\$2011\} & $\{6.65\}$ & $\{7.46\}$ & $\{5.99\}$ & $\{6.47\}$ & $\{5.67\}$ & $\{6.28\}$ \\
\hline \multicolumn{7}{|l|}{$800 \mathrm{~m}$ train catchment } \\
\hline number of parcels & 15998 & 4643 & 5068 & 4000 & 890 & 1396 \\
\hline ( $\%$ of total catchment number of parcels) & $(3.5 \%)$ & $(16.3 \%)$ & $(5.9 \%)$ & $(5.9 \%)$ & $(0.7 \%)$ & $(0.9 \%)$ \\
\hline [Ave. Catch. LandVal./m² AUD\$2011] & {$[1002.33]$} & {$[1930.44]$} & {$[466.18]$} & {$[770.63]$} & {$[588.45]$} & [789.61] \\
\hline$\{$ Ave. Catch. Log LandVal./m² AUD\$2011\} & $\{6.62\}$ & $\{7.50\}$ & $\{5.96\}$ & $\{6.57\}$ & $\{6.16\}$ & $\{6.52\}$ \\
\hline \multicolumn{7}{|l|}{$1600 \mathrm{~m}$ train catchment } \\
\hline number of parcels & 51388 & 6797 & 15749 & 7424 & 9238 & 12179 \\
\hline (\% of total catchment number of parcels) & $(11.1 \%)$ & $(23.9 \%)$ & $(18.5 \%)$ & $(11.0 \%)$ & $(7.2 \%)$ & $(8.0 \%)$ \\
\hline [Ave. Catch. LandVal./m² AUD\$ 2011] & {$[768.32]$} & {$[1961.71]$} & {$[403.95]$} & {$[800.36]$} & {$[555.87]$} & [713.54] \\
\hline$\{$ Ave. Catch. Log LandVal./m² AUD\$2011\} & $\{6.35\}$ & $\{7.48\}$ & $\{5.84\}$ & $\{6.55\}$ & $\{6.09\}$ & $\{6.47\}$ \\
\hline $0-100 \mathrm{~m}$ of a Hwy \# of parcels & 17811 & 1306 & 3746 & 2585 & 4753 & 5420 \\
\hline (\% of total) & $(3.9 \%)$ & $(4.5 \%)$ & $(4.4 \%)$ & $(3.8 \%)$ & $(3.7 \%)$ & $(3.5 \%)$ \\
\hline $100-200 \mathrm{~m}$ of a Hwy \# of parcels & 26215 & 2355 & 5365 & 4566 & 7108 & 6820 \\
\hline (\% of total) & $(5.7 \%)$ & $(8.3 \%)$ & $(6.3 \%)$ & $(6.7 \%)$ & $(5.5 \%)$ & $(4.5 \%)$ \\
\hline $200-400 \mathrm{~m}$ of a Hwy \# of parcels & 48942 & 4105 & 9643 & 8106 & 13784 & 13302 \\
\hline (\% of total) & $(5.7 \%)$ & $(14.4 \%)$ & $(11.3 \%)$ & $(12.0 \%)$ & $(10.8 \%)$ & $(8.7 \%)$ \\
\hline Distance to nearest freeway onramp & 8.63 & 6.89 & 13.54 & 17.41 & 5.52 & 4.94 \\
\hline \multicolumn{7}{|l|}{ Transportation Accessibility Measure } \\
\hline SNAMUTS score & 6.62 & 11.02 & 7.34 & 5.58 & 6.98 & 5.56 \\
\hline \# of Dwellings within $1600 \mathrm{~m}$ of parcel & 4680 & 5772 & 4228 & 3880 & 4404 & 5314 \\
\hline Distance to CBD $(\mathrm{km})$ & 17.422 & 12.16 & 17.97 & 18.37 & 18.76 & 16.56 \\
\hline Distance to secondary centre $(\mathrm{km})$ & 4.80 & 2.44 & 5.10 & 6.78 & 5.33 & 3.75 \\
\hline \multicolumn{7}{|l|}{ Property and Locational Attributes } \\
\hline Area $\left(\mathrm{m}^{2}\right)$ & 1746 & 688 & 2067 & 4072 & 1488 & 942 \\
\hline R-Code & 20.98 & 21.11 & 21.56 & 18.81 & 20.52 & 22.36 \\
\hline Senior high school rating & 5.52 & 17.34 & 7.33 & 2.80 & 4.88 & 7.05 \\
\hline Socio Economic Index For Areas (SEIFA) & 58.641 & 87.49 & 42.39 & 51.88 & 60.89 & 63.43 \\
\hline Distance to water $(\mathrm{km})$ & 3.17 & 1.15 & 5.01 & 4.08 & 2.13 & 3.00 \\
\hline
\end{tabular}


The results of the panel data Log-Log HPM study are shown in Table 7, with the majority of the models reporting strongly with coefficients of determination (or adjusted r-squared values) over 70 percent, which is the suggested minimum level of explanatory power for hedonic models in predicting land values (Hannonen 2009, p. 159-160; McCarthy 2001, p. 32-39). The cross-sectional model highlights the counterintuitive negative Joondalup and Mandurah rail coefficients, which were due to the negative externalities of proximity to the freeway. The panel data model was adopted for forecasting since this highlighted the impact of the relative change in accessibility and hedonic price, which is a truer representation of the value uplift in land markets that the study was seeking to address.

The panel data model demonstrated that the hedonic price change between funding commitment and transit opening for the Mandurah Line ranged from 40 percent for the $400 \mathrm{~m}$ catchment to 13 percent for the $1600 \mathrm{~m}$ catchment. This is a significant difference in land values due to the new rail system accessibility.

The historic data examination of the introduction of the rail line within the Mandurah subregion therefore tells a substantially different story than the one portrayed by the cross-sectional analyses for 2011, and it is a critical aspect of the analysis of the rail transit accessibility and value capture potential. Instead of having a minimal impact on land value (due to the freeway the train runs down), there is indeed a rapidly growing land value increase of up to 40 percent, which is as high as most other studies have shown. The potential for the Mandurah Line to impact government revenue and the attractiveness of transit oriented land development is large, despite it being in a highly car dependent corridor.

The increase in real property prices over the regional averages shown in Table 6 has significantly impacted the existing taxation and charges for the three tiers of government. These impacts on government taxation and charges were not included in the forecasting at the time of the investment in the Mandurah Line and as such did not appear in the project's financial cash flow analysis or business case. These passive increases could have been financially modeled and included in the project business case and subsequently used to defray the cost of the project. 
Table 7: OLS panel data (Log-Log) HPM of residential properties (2001-2011): Fremantle (1), Armadale (2), Midland (3), Mandurah (4), and Joondalup (5)

\begin{tabular}{|c|c|c|c|c|c|c|}
\hline Explanatory Variables & All Regions & (1) & $(2)$ & (3) & $(4)$ & (5) \\
\hline Const & $\begin{array}{c}6.048 \\
(0.006)^{* * *} \\
\end{array}$ & $\begin{array}{c}9.010 \\
(0.022)^{* * *}\end{array}$ & $\begin{array}{c}6.223 \\
(0.010)^{* * *} \\
\end{array}$ & $\begin{array}{c}6.877 \\
(0.010)^{* * *}\end{array}$ & $\begin{array}{c}-1.124 \\
(0.02)^{* * *}\end{array}$ & $\begin{array}{c}4.113 \\
(0.011)^{* * *}\end{array}$ \\
\hline ln_area & $\begin{array}{c}-0.516 \\
(0.000)^{* * *}\end{array}$ & $\begin{array}{c}-0.412 \\
(0.001)^{* * *}\end{array}$ & $\begin{array}{c}-0.535 \\
(0.001)^{* * *}\end{array}$ & $\begin{array}{c}-0.558 \\
(0.001)^{* * *}\end{array}$ & $\begin{array}{c}-0.390 \\
(0.0001)^{* * *}\end{array}$ & $\begin{array}{c}-0.375 \\
(0.001)^{* * *}\end{array}$ \\
\hline ln_rcode & $\begin{array}{c}0.024 \\
(0.001)^{* * *}\end{array}$ & $\begin{array}{c}-0.023 \\
(0.002)^{* * *}\end{array}$ & $\begin{array}{c}0.013 \\
(0.001)^{* * *} \\
\end{array}$ & $\begin{array}{c}0.055 \\
(0.001)^{* * *}\end{array}$ & $\begin{array}{c}0.102 \\
(0.001)^{* * *}\end{array}$ & $\begin{array}{c}0.334 \\
(0.001)^{* * *}\end{array}$ \\
\hline train 400 & $\begin{array}{c}0.235 \\
(0.005)^{* * *}\end{array}$ & $\begin{array}{c}0.228 \\
(0.007)^{* * *} \\
\end{array}$ & $\begin{array}{c}-0.142 \\
(0.007)^{* * *}\end{array}$ & $\begin{array}{c}0.071 \\
(0.007)^{* * *}\end{array}$ & $\begin{array}{c}-0.337 \\
(0.002)^{* * *}\end{array}$ & $\begin{array}{c}-0.269 \\
(0.018)^{* * *}\end{array}$ \\
\hline train 800 & $\begin{array}{c}0.176 \\
(0.003)^{* * *}\end{array}$ & $\begin{array}{c}0.252 \\
(0.005)^{* * *} \\
\end{array}$ & $\begin{array}{c}-0.123 \\
(0.004)^{* * *}\end{array}$ & $\begin{array}{c}0.093 \\
(0.004) \\
\end{array}$ & $\begin{array}{c}-0.094 \\
(0.001)^{* * *}\end{array}$ & $\begin{array}{c}-0.050 \\
(0.009)^{* * *}\end{array}$ \\
\hline train 1600 & $\begin{array}{c}0.074 \\
(0.001)^{* * *} \\
\end{array}$ & $\begin{array}{c}0.180 \\
(0.004)^{* * *} \\
\end{array}$ & $\begin{array}{c}-0.130 \\
(0.002)^{* * *}\end{array}$ & $\begin{array}{c}0.148 \\
(0.004)^{* * *}\end{array}$ & $\begin{array}{c}-0.034 \\
(0.003)^{* * *} \\
\end{array}$ & $\begin{array}{c}-0.008 \\
(0.003)^{* * *}\end{array}$ \\
\hline ln_snamuts & $\begin{array}{c}0.003 \\
(0.000)^{* * *} \\
\end{array}$ & $\begin{array}{c}-0.006 \\
(0.0001)^{* * *}\end{array}$ & $\begin{array}{c}0.007 \\
(0.0001)^{* * *}\end{array}$ & $\begin{array}{c}0.011 \\
(0.0001)^{* * *}\end{array}$ & $\begin{array}{c}-0.009 \\
(0.0001)^{* * *}\end{array}$ & $\begin{array}{c}0.010 \\
(0.0006)^{* * *} \\
\end{array}$ \\
\hline ln_seifa_adv_di & $\begin{array}{c}0.304 \\
(0.000)^{* * *} \\
\end{array}$ & $\begin{array}{c}0.166 \\
(0.002)^{* * *} \\
\end{array}$ & $\begin{array}{c}0.202 \\
(0.0004)^{* * *}\end{array}$ & $\begin{array}{c}0.205 \\
(0.001)^{* * *}\end{array}$ & $\begin{array}{c}0.283 \\
(0.0004)^{* * *}\end{array}$ & $\begin{array}{c}0.281 \\
(0.0005)^{* * *} \\
\end{array}$ \\
\hline ln_shsrate11 & $\begin{array}{c}0.058 \\
(0.000)^{* * *} \\
\end{array}$ & $\begin{array}{c}0.171 \\
(0.001)^{* * *}\end{array}$ & $\begin{array}{c}0.055 \\
(0.0001)^{* * *}\end{array}$ & $\begin{array}{c}0.023 \\
(0.0001)^{* * *}\end{array}$ & $\begin{array}{c}0.030 \\
(0.0001)^{\text {*** }}\end{array}$ & $\begin{array}{c}0.045 \\
(0.0008)^{* * *} \\
\end{array}$ \\
\hline ln_dist_water & $\begin{array}{c}-0.183 \\
(0.000)^{* * *}\end{array}$ & $\begin{array}{c}-0.241 \\
(0.001)^{* * *}\end{array}$ & $\begin{array}{c}-0.053 \\
(0.0004)^{* * *}\end{array}$ & $\begin{array}{c}-0.094 \\
(0.0004)^{* * *}\end{array}$ & $\begin{array}{c}-0.214 \\
(0.0003)^{* * *}\end{array}$ & $\begin{array}{c}-0.200 \\
(0.0003)^{* * *}\end{array}$ \\
\hline ln_dwell_1600 & $\begin{array}{c}0.157 \\
(0.000)^{* * *} \\
\end{array}$ & $\begin{array}{c}-0.165 \\
(0.002)^{* * *} \\
\end{array}$ & $\begin{array}{c}0.173 \\
(0.001)^{* * *} \\
\end{array}$ & $\begin{array}{c}0.125 \\
(0.001)^{* * *} \\
\end{array}$ & $\begin{array}{c}0.206 \\
(0.0007)^{* * *}\end{array}$ & $\begin{array}{c}0.175 \\
(0.0001)^{* * *} \\
\end{array}$ \\
\hline ln_dist_cbd & $\begin{array}{c}-0.028 \\
(0.000)^{* * *} \\
\end{array}$ & $\begin{array}{c}-0.012 \\
(0.001)^{* * *} \\
\end{array}$ & $\begin{array}{c}-0.001 \\
(0.0003)^{* * *}\end{array}$ & $\begin{array}{c}-0.023 \\
(0.0003)^{* * *}\end{array}$ & $\begin{array}{c}-0.004 \\
(0.0003)^{* * *}\end{array}$ & $\begin{array}{c}-0.041 \\
(0.0003)^{* * *} \\
\end{array}$ \\
\hline ln_dist_ctr_non & $\begin{array}{c}-0.034 \\
(0.000)^{* * *} \\
\end{array}$ & $\begin{array}{c}-0.062 \\
(0.001)^{* * *} \\
\end{array}$ & $\begin{array}{c}0.025 \\
(0.0003)^{* * *}\end{array}$ & $\begin{array}{c}-0.009 \\
(0.0004)^{* * *}\end{array}$ & $\begin{array}{c}-0.004 \\
(0.0003)^{* * *}\end{array}$ & $\begin{array}{c}0.005 \\
(0.0003)^{* * *} \\
\end{array}$ \\
\hline hwy0_100 & $\begin{array}{c}-0.077 \\
(0.001)^{* * *} \\
\end{array}$ & $\begin{array}{c}-0.165 \\
(0.002)^{* * *} \\
\end{array}$ & $\begin{array}{c}-0.075 \\
(0.001)^{* * *} \\
\end{array}$ & $\begin{array}{c}-0.107 \\
(0.002)^{* * *} \\
\end{array}$ & $\begin{array}{c}-0.053 \\
(0.0001)^{* * *}\end{array}$ & $\begin{array}{c}-0.015 \\
(0.001)^{* * *} \\
\end{array}$ \\
\hline hwy100_200 & $\begin{array}{c}0.006 \\
(0.001)^{* * *} \\
\end{array}$ & $\begin{array}{c}-0.062 \\
(0.002)^{* * *} \\
\end{array}$ & $\begin{array}{c}-0.018 \\
(0.001)^{* * *}\end{array}$ & $\begin{array}{c}-0.025 \\
(0.001)^{* * *}\end{array}$ & $\begin{array}{c}0.041 \\
(0.001)^{* * *} \\
\end{array}$ & $\begin{array}{c}0.049 \\
(0.001)^{* * *} \\
\end{array}$ \\
\hline ln_fwyonramp & $\begin{array}{c}0.026 \\
(0.000)^{* * *} \\
\end{array}$ & $\begin{array}{c}0.021 \\
(0.001)^{* * *} \\
\end{array}$ & $\begin{array}{c}-0.013 \\
(0.0004)^{* * *}\end{array}$ & $\begin{array}{c}-0.089 \\
(0.001)^{* * *}\end{array}$ & $\begin{array}{c}0.015 \\
(0.0001)^{* * *}\end{array}$ & $\begin{array}{c}0.032 \\
(0.0003)^{* * *} \\
\end{array}$ \\
\hline dt_2002 & $\begin{array}{c}0.067 \\
(0.001)^{* * *}\end{array}$ & $\begin{array}{c}0.081 \\
(0.003)^{* * *}\end{array}$ & $\begin{array}{c}0.018 \\
(0.001)^{* * *}\end{array}$ & $\begin{array}{c}0.047 \\
(0.002)^{* * *}\end{array}$ & $\begin{array}{c}0.058 \\
(0.001)^{* * *}\end{array}$ & $\begin{array}{c}0.082 \\
(0.001)^{* * *}\end{array}$ \\
\hline dt_2003 & $\begin{array}{c}0.18 \\
(0.001)^{* * *}\end{array}$ & $\begin{array}{c}0.164 \\
(0.003)^{* * *} \\
\end{array}$ & $\begin{array}{c}0.101 \\
(0.002)^{* * *}\end{array}$ & $\begin{array}{c}0.163 \\
(0.002)^{* * *}\end{array}$ & $\begin{array}{c}0.178 \\
(0.001)^{* * *}\end{array}$ & $\begin{array}{c}0.210 \\
(0.001)^{* * *}\end{array}$ \\
\hline dt_2004 & $\begin{array}{c}0.367 \\
(0.001)^{* * *}\end{array}$ & $\begin{array}{c}0.301 \\
(0.003)^{* * * *}\end{array}$ & $\begin{array}{c}0.259 \\
(0.002)^{* * *}\end{array}$ & $\begin{array}{c}0.317 \\
(0.002)^{* * *}\end{array}$ & $\begin{array}{c}0.374 \\
(0.001)^{* * *} \\
\end{array}$ & $\begin{array}{c}0.419 \\
(0.001)^{* * *}\end{array}$ \\
\hline dt_2005 & $\begin{array}{c}0.549( \\
0.001)^{* * *}\end{array}$ & $\begin{array}{c}0.428 \\
(0.003)^{* * *} \\
\end{array}$ & $\begin{array}{c}0.464 \\
(0.002)^{* * *}\end{array}$ & $\begin{array}{c}0.505 \\
(0.002)^{* * *}\end{array}$ & $\begin{array}{c}0.598 \\
(0.001)^{* * *}\end{array}$ & $\begin{array}{c}0.565 \\
(0.001)^{* * *}\end{array}$ \\
\hline dt_2006 & $\begin{array}{c}0.769 \\
(0.001)^{* * *} \\
\end{array}$ & $\begin{array}{c}0.577 \\
(0.003)^{* * *} \\
\end{array}$ & $\begin{array}{c}0.730 \\
(0.002)^{* * *}\end{array}$ & $\begin{array}{c}0.765 \\
(0.002)^{* * *}\end{array}$ & $\begin{array}{c}0.796 \\
(0.001)^{* * *}\end{array}$ & $\begin{array}{c}0.781 \\
(0.001)^{* * *} \\
\end{array}$ \\
\hline dt_2007 & $\begin{array}{c}1.187 \\
(0.001)^{* * *} \\
\end{array}$ & $\begin{array}{c}0.869 \\
(0.003)^{* * *} \\
\end{array}$ & $\begin{array}{c}1.175 \\
(0.002)^{* * *} \\
\end{array}$ & $\begin{array}{c}1.216 \\
(0.002)^{* * *} \\
\end{array}$ & $\begin{array}{c}1.165 \\
(0.001)^{* * *} \\
\end{array}$ & $\begin{array}{c}1.23 \\
(0.001)^{* * *} \\
\end{array}$ \\
\hline dt_2008 & $\begin{array}{c}1.315 \\
(0.001)^{* * *} \\
\end{array}$ & $\begin{array}{c}1.070 \\
(0.003)^{* * *}\end{array}$ & $\begin{array}{c}1.319 \\
(0.002)^{* * *}\end{array}$ & $\begin{array}{c}1.387 \\
(0.002)^{* * *} \\
\end{array}$ & $\begin{array}{c}1.314 \\
(0.001)^{* * *} \\
\end{array}$ & $\begin{array}{c}1.318 \\
(0.001)^{* * *} \\
\end{array}$ \\
\hline dt_2009 & $\begin{array}{c}1.24 \\
(0.001)^{* * *} \\
\end{array}$ & $\begin{array}{c}1.015 \\
(0.0003)^{* * *} \\
\end{array}$ & $\begin{array}{c}1.258 \\
(0.002)^{* * *} \\
\end{array}$ & $\begin{array}{c}1.348 \\
(0.002)^{* * *} \\
\end{array}$ & $\begin{array}{c}1.247 \\
(0.001)^{* * *} \\
\end{array}$ & $\begin{array}{c}1.217 \\
(0.001)^{* * *} \\
\end{array}$ \\
\hline dt_2010 & $\begin{array}{c}1.25 \\
(0.001)^{* * *}\end{array}$ & $\begin{array}{c}0.994 \\
(0.003)^{* * *} \\
\end{array}$ & $\begin{array}{c}1.273 \\
(0.002)^{* * *}\end{array}$ & $\begin{array}{c}1.349 \\
(0.002)^{* * *}\end{array}$ & $\begin{array}{c}1.234 \\
(0.001)^{* * *}\end{array}$ & $\begin{array}{c}1.252 \\
(0.001)^{* * *} \\
\end{array}$ \\
\hline dt_2011 & $\begin{array}{c}1.323 \\
(0.001)^{* * * *} \\
\end{array}$ & $\begin{array}{c}1.071 \\
(0.003)^{* * *} \\
\end{array}$ & $\begin{array}{c}1.355 \\
(0.002)^{* * *} \\
\end{array}$ & $\begin{array}{c}1.409 \\
(0.002)^{* * *}\end{array}$ & $\begin{array}{c}1.297 \\
(0.001)^{* * *}\end{array}$ & $\begin{array}{c}1.324 \\
(0.001)^{* * *} \\
\end{array}$ \\
\hline \multicolumn{7}{|l|}{ Congruence Statistics } \\
\hline No. of Observations & $4,431,363$ & 297,855 & 795,028 & 595,669 & $1,200,898$ & $1,541,913$ \\
\hline Adjusted R-Squared & $84.60 \%$ & $81.98 \%$ & $91.12 \%$ & $92.16 \%$ & $87.20 \%$ & $80.32 \%$ \\
\hline Standard Error of Reg. & 0.336 & 0.250 & 0.239 & 0.311 & 0.280 & 0.243 \\
\hline
\end{tabular}

Notes: Figures in brackets report parameter standard errors. Significance at the 0.01 level is indicated by three asterisks, significance at the 0.05 level is indicated by two asterisks, and significance at the 0.10 level is indicated by a single asterisk. Interaction terms between time dummies and train catchments are omitted here for brevity, but the annual uplift estimates can be seen plotted in Figure 16. 


\subsection{Step 4: Analysis of the value capture mechanisms available}

In partnership with the WATC, a detailed financial model was created to analyze the present value calculation of passive and active value capture mechanisms for the investment in the Mandurah Line compared to a hypothetical base case in which the Mandurah Line was never built. The results for both the passive and active mechanisms are presented in Figure 4.

\subsubsection{Passive value capture mechanisms}

The impact of the increase in land values translates to the commonwealth government taxes (capital gains tax and GST), Western Australian state taxes (land tax, MRIT, stamp duty), and local government (council rates) over the financial periods 2001-2031. The modeled impact on the tax system of the investment in the rail line was substantial and accounts for approximately $\$ 506$ million dollars (or 30 percent) of capital expenditure (AUD 2013). This equates to a 30 percent increase in the ad valorem taxes for the primary $400 \mathrm{~m}$ pedestrian catchment surrounding the Mandurah rail station precincts compared to the non-transit base case.

\subsubsection{Active value capture mechanisms}

In addition to the passive tax benefits from the investment in the Mandurah Line, a scenario was developed supposing some active value capture mechanisms were put in place within the existing $800 \mathrm{~m}$ pedestrian catchments that included:

- 10 percent differential increase in local government rates,

- $\$ 100$ annual specified area levy/property,

- \$100 annual service charge/property,

- 5 percent density bonus on post title sale proceeds for extra permitted floor area, and

- 50 percent reduction in new development car parking, with bay costs to be taken as cash in lieu.

These mechanisms are presented individually and are not designed to be implemented together (though they can be). Since there was minimal to no intensification within the $800 \mathrm{~m}$ pedestrian catchment after the commencement of the rail line, and the only intensification to merely develop up to the permitted low density with no increase in zoning, the development-based mechanisms will be of little impact compared to an intensification-based scenario.

However, if further rezoning of the land around the stations to facilitate intensification of the land uses were to occur to further facilitate land and transit integration, this would lead to even greater uplift in the land values around the stations (represented in the R-Code Elasticity in Table 5) and importantly increase the amount of development within the catchments to be impacted by the passive and active mechanisms. To illustrate the impact of intensification, a 400 percent increase in residential density in the $400 \mathrm{~m}$ pedestrian catchment land catchment scenario was run, with the results presented in Figure 6. Although this increase could be interpreted as excessive, it merely raises the residential density to the levels of the Subiaco TOD in Perth, which is now being exceeded by new significant government TOD projects at two of the Mandurah Line stations.

The passive and active mechanism revenue for the "no intensification" scenario was substantial at just over $\$ 750$ million (AUD 2013), but with the intensification scenario this increased to over $\$ 1.7$ billion (AUD 2013). These are significant project-induced revenues, which equate to 60 percent and 132 percent of the capital cost of the Mandurah Line, respectively. While not all of these revenues are able 
to be captured (e.g., commonwealth government taxes), or in some cases actually economically efficient (e.g., developer contributions), they form an important part of the development of the project's financial performance over a 30-year project operating period.

Each of the value capture mechanisms proposed in the "no intensification" scenario are assessed in an evaluation matrix ${ }^{3}$ (presented in Table 8), and this enables a transparent analysis of each of the mechanisms proposed. However, it is worth noting that a weighting for each of the assessment criteria would be conducted with the relevant stakeholders as part of the assessment process.

\footnotetext{
${ }^{3}$ The evaluation matrix proposed highlights both quantitative and qualitative metrics and enables the analysis of financial and economic factors together.
} 


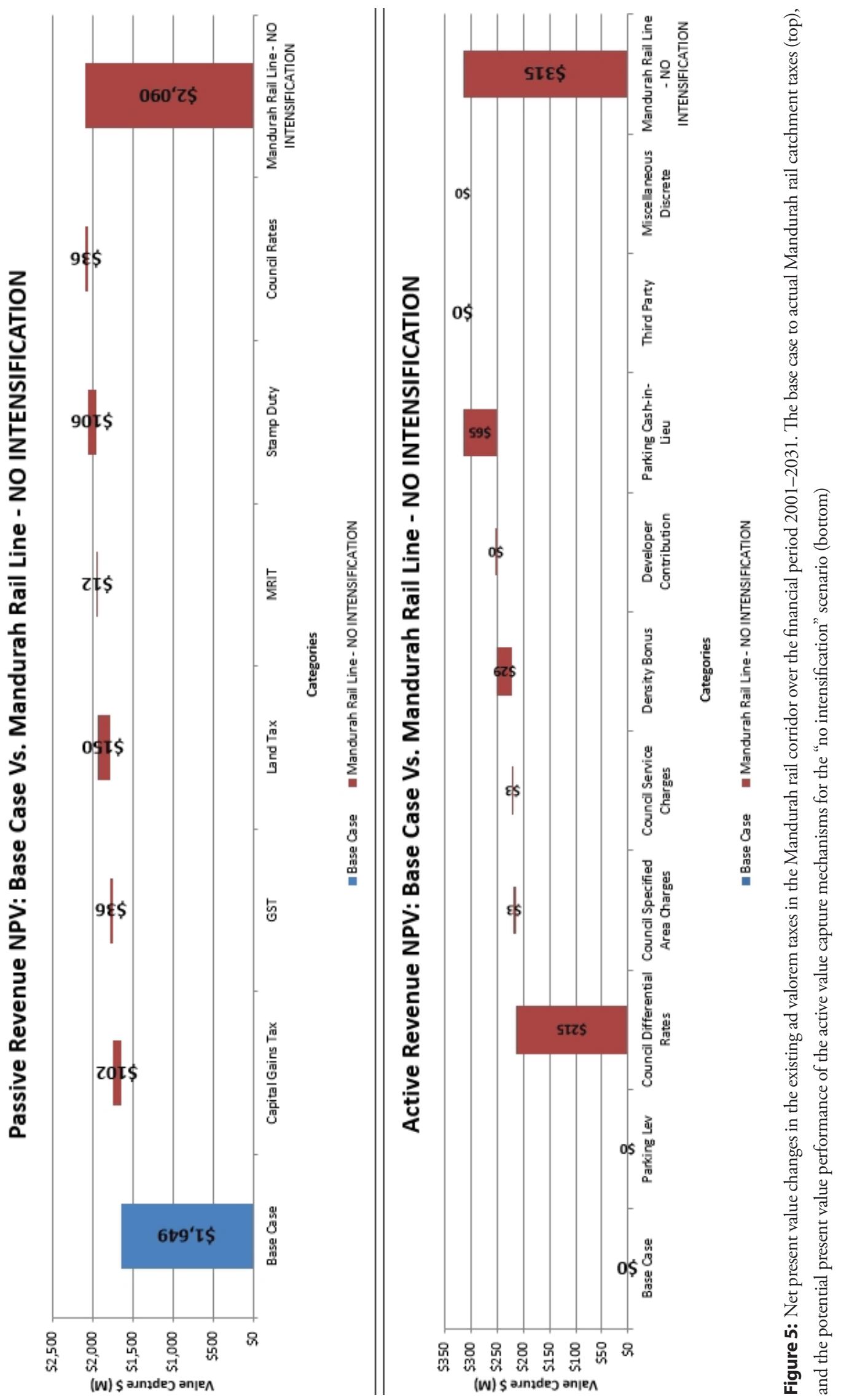




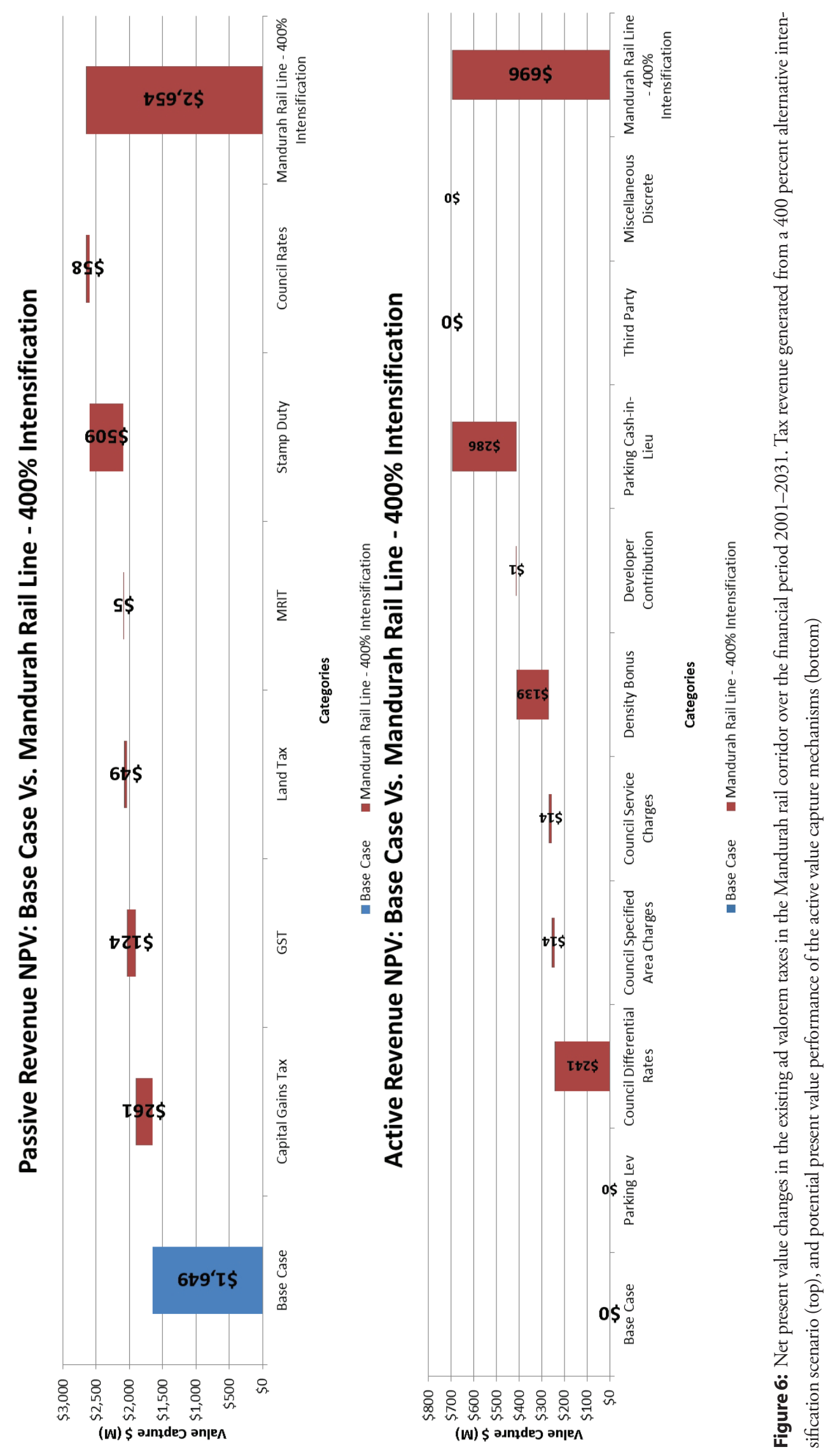


Table 8: An unweighted Transit Project Value Capture Mechanism Analysis Matrix for the no intensification base case

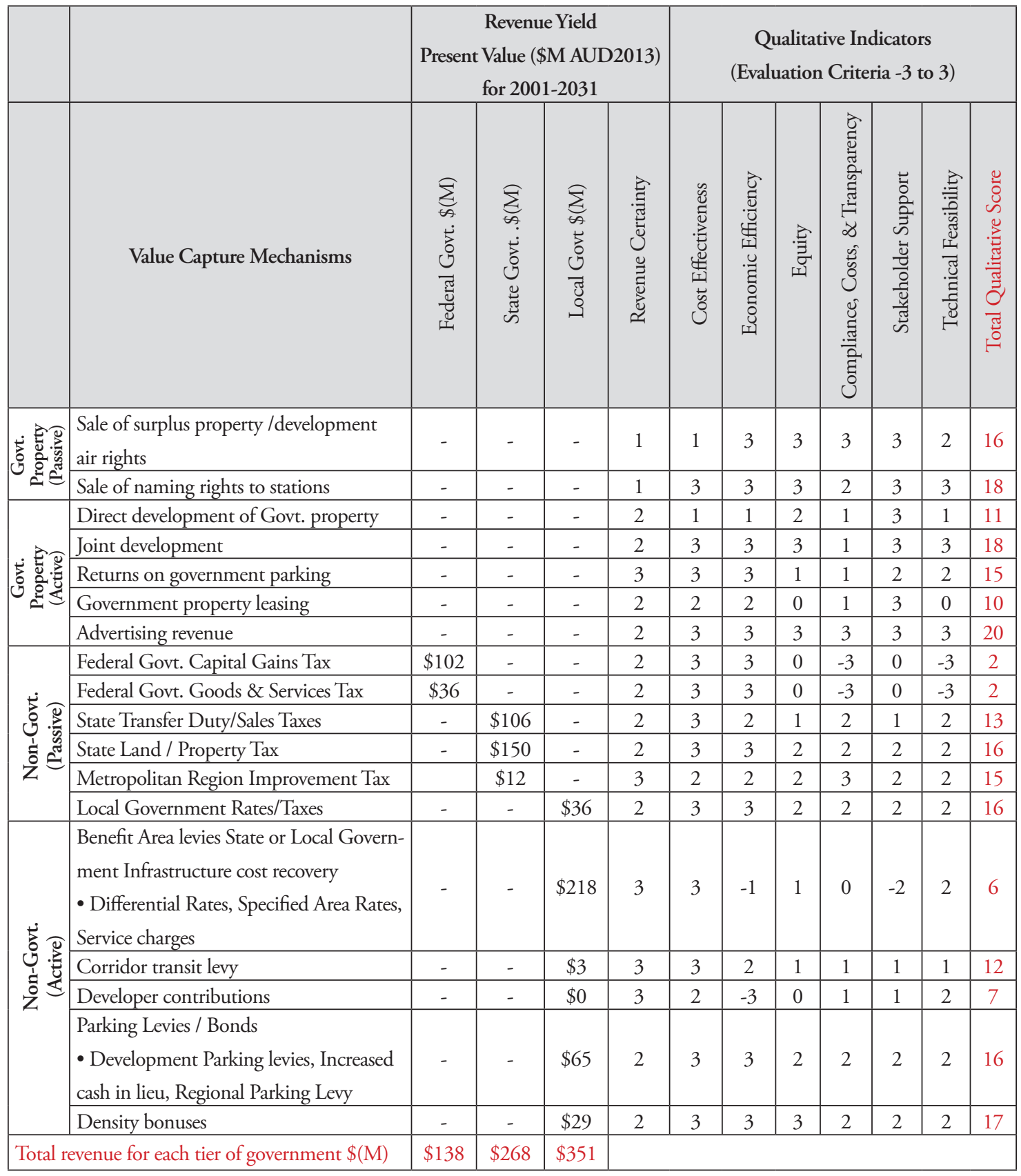

Notes:

1. Not all the mechanisms were applicable to the Mandurah rail line and hence were not financially assessed, though they were all qualitatively assessed for application suitability. Lack of information on the nature and amount of government property in the corridor inhibited this assessment, though this could be rectified for future assessments of the corridor.

2. Qualitative Indicators Evaluation Criteria: 3 (Strong Performance), 1 (Modest Performance), 0 (Marginal Performance), -1 (Moderately Poor Performance), -3 (Very Poor Performance). 


\subsection{Step 5: Establish a procurement strategy through a fund to hypothecate all value capture funds for project financing and implementation plan}

As the Mandurah Line has been built, the estimated revenue that could have been raised suggests it would have been enough for the construction and even part of the ongoing operations of the line if the project had been developed using a value capture framework. We suggest that a value capture fund called the Metropolitan Region Transit Fund (MRTF) could have been established and that the transit fund could have captured project-based active value capture benefits and passive taxes through hypothecated funds from existing legislative tools and then facilitated by a TIF. In fact, any value capture fund could facilitate the creation of a loan mechanism to fund the capital costs of the investment in transit infrastructure.

The creation of a value capture fund requires all levels of government to agree to its terms of reference, an integrated land-use and transportation focus, and importantly the development of a delivery agency to manage the investment of its funds. The significant outcome of creating transit-oriented land uses has been given a considerable boost through this kind of process, but to optimize implementation a delivery agency will need to focus on these outcomes as well as building the transit (Renne and Wells 2005; Cervero et al. 2002).

An implementation strategy for the next stages of Perth's rail system could be based on a completely public approach, involve a mostly private-sector approach, or involve a blend of the two, as with Western Australia's Metropolitan Redevelopment Authority. It is possible for Perth to implement a largely private rail project based on the above value capture analyses, as this enables private sector involvement and capital required to facilitate innovation in building and operating a new rail system and in development around highly valuable sites along the route. The alternative funding framework could be applied to any car-dependent urban system looking to create a way out of its car-based dilemmas.

\section{Conclusion}

This paper presents the merits of bringing metropolitan region strategic land-use and transit planning together with strategic funding mechanisms to enable implementation of transit infrastructure and reurbanization. Most car-dependent cities, such as those in the United States and Australia, are attempting to rebuild in this way. The paper has outlined a value capture framework that in five steps can determine the potential to use value capture to fund a new transit system.

The process will necessarily involve all tiers of government to help distribute the project cost equitably and use the different powers available. The Perth case study shows that substantial funds could have been generated with the government mechanisms currently available. The reality is that most if not all of the funding could have been obtained by this mechanism. It also shows that the funding could have enabled private-sector involvement and would have achieved significantly more TODs with many more people therefore having easy access to the transit line. While there may be challenges in setting up these value capture mechanisms, not doing so would mean that cities, especially car-dependent cities, would be more poorly placed socially, environmentally, and economically. The global turn to transit and re-urbanization has left many cities without the funds to support the financing required to enable the investment in transit infrastructure and TOD, and this paper proposes a framework to enable this. 


\section{Acknowledgements}

The authors of this paper would like to thank the following organizations for the support and provision of data necessary to conduct the research undertaken:

- Western Australian Treasury Corporation

- Western Australian Valuer Generals Office, Landgate

\section{$7 \quad$ Funding}

This work was supported by the Australian Government Cooperative Research Centre for Spatial Information (CRCSI) and the Planning and Transport Research Centre (PATREC) through the provision of a PhD scholarship to James McIntosh.

\section{References}

Agostini, C. and G. Palmucci. 2008. The anticipated capitalisation effect of a new metro line on housing prices. Fiscal Studies 29(2): 233-256.

Al-Mosaind, M., K. Dueker, and J. Strathman. 1993. Light rail transit stations and property values. Transportation Research Record 1400: 90-94.

Alonso, W. 1964. Location and Land-use: Towards a General Theory of Land Rent. Harvard University Press, Cambridge.

Allen, B. 1987. Value capture in transit. Journal of the Transportation Research Forum 28: 50-57.

Allen Consulting Group. 2003. Funding for Urban Public Infrastructure (report for the Property Council of Australia).

American Public Works Association. 2003. Financing Stormwater Utilities (downloaded from http:// www2.apwa.net/bookstore/detail.asp?PC=PB.AFSF).

Armstrong, R. 1994. Impacts of commuter rail service as reflected in single-family residential property values. Transportation Research Record 1466: 88-98.

Bae, C., M. Jun, and H. Park. 2003. The impact of Seoul's subway Line 5 on residential property values. Transport Policy 10(2): 85-94.

Ball, M. 1973. Recent empirical work of the determinants of relative house prices. Urban Studies 10: 213-233.

Bartholomew, K. and R. Ewing. 2011. Hedonic price effects of pedestrian and transit-oriented development. Journal of Planning Literature 26(1): 18-34

Batt, W. 2001. Value capture as a policy tool in transportation economics: in exploration in public finance in the tradition of Henry George. American Journal of Economics and Sociology 60(1): 195228.

Center for Transit-Oriented Development. 2008. Capturing the Value of Transit. Oakland, CA. (Downloaded from: http://www.reconnectingamerica.org/public/display_asset/ctodvalcapture110508v2).

Cervero, R. 1993. Ridership Impacts of Transit-Focssed Development in California. Berkeley: Institute of Urban and Regional Development, University of California, Monograph 45.

- 1994. Rail transit and joint development: land market impacts in Washington, D.C. and Atlanta. Journal of the American Planning Association 60(1): 83-94.

- 1997. Transit-Induced Accessibility and Agglomeration Benefits: A Land Market Evaluation. Berkeley, Institute of Urban and Regional Development, University of California, Berkeley, Working Paper 691. 
2004. Effects of light and commuter rail transit on land prices: experiences in San Diego County. Journal of the Transportation Research Forum 43(1): 121-138.

Cervero, R. and M. Duncan. 2002. Rail's added value. Urban Land 61(2): 77-84.

Cervero, R., C. Ferrell, and S. Murphy. 2002. Transit-oriented development and joint development in the United States: A literature review. TCRP Research Results Digest 52.

Cervero, R., P. Hall, and J. Landis. 1993. Transit and Joint Development in the United States. University of California Berkeley, Institute of Urban and Regional Development.

Cervero, R. and C. D. Kang. 2011. Bus rapid transit impacts on land uses and land values in Seoul, Korea. Transport Policy 18(1): 102-116.

Cervero, R. and K. Kockelman. 1997. Travel demand and the 3Ds: density, diversity and design. Transportation Research Part D: Transport and Environment 2(3): 199-219.

Cervero, R. and J. Murakami. 2009. Rail and property development in Hong Kong: experiences and extensions. Urban Studies 46(10): 2019-2043.

Debrezion, G., E. Pels, and P. Rietveld. 2007. The impact of railway stations on residential and commercial property value: A meta analysis. Journal of Real Estate Finance and Economics 35(2): 161-80.

Day, P. 1992. Land Value Capture. A report to the Local Government Association of Queensland, February.

Diaz, R. 1999. Impacts of rail transit on property values. In Commuter Rail/Rapid Transit Conference Proceedings, Toronto. American Public Transit Association: 66-73.

Du, H. and C. Mulley. 2007. Transport accessibility and land values: A case study of Tyne and Wear. Report RICS Research Paper Series 3(7).

Duncan, M. 2008. Comparing rail transit capitalization benefits for single-family and condominium units in San Diego, CA. Transportation Research Record 2067: 120-130.

Espada, I. 2010. Application of accessibility measures progress report 2: model calibration and preliminary application results. Austroads, Report No. NS1586-5.

Espada, I. and J. Luk. 2011. Development of an accessibility metric and its application to Melbourne. Roads and Transport Research 20(2): 66-77.

Ewing, R. and R. Cervero. 2010. Travel and the built environment. Journal of the American Planning Association 76(3): 265-294.

Fejarang, R. 1994. Impact on property values: A study of the Los Angeles Metro Rail. Transportation Research Board (preprint, Transportation Research Board, 73rd Annual Meeting: 9-13).

Garrett, T. 2004. Light rail in America: Policy issues and prospects for economic development. Unpublished Manuscript, Federal Reserve Bank of St. Louis, Research Department.

Goodwin, P. 2012. Three views on peak car. World Transport Policy and Practice 17(4): 8-17.

Giuliano, G., P. Gordon, Q. Pan, and J. Park. 2010. Accessibility and residential land values: some tests with new measures. Urban Studies 47(14): 3103-3130.

Gruen, A. 1997. The Effect of CTA and METRA Stations on Residential Property Values. Regional Transportation Authority.

Hannonen, M. 2009. Hedonic Modelling in Land Markets —A Modern Approach. VDM Verlag Dr. Müller.

Hanson, S. 1995. The Geography of Urban Transportation. Second Edition, New York: Guilford Press.

Hui, E. and V. Ho. 2004. Land value capture mechanisms in Hong Kong and Singapore. A comparative analysis. Journal of Property Investment \& Finance 22(1): 76-100. 
Iacono, M., D. Levinson, J. Zhao, and A. Lari. 2009. Value Capture for Transportation Finance: Report to the Minnesota Legislature (Value Capture for Transportation Finance Series, Report No. CTS 0918S). Minneapolis: University of Minnesota Center for Transportation Studies. Downloaded from: http://www.cts.umn.edu/Publications/ResearchReports/reportdetail.html?id=1800.

Jacobs, J. 1969. The Economy of Cities. New York: Random House.

Kenworthy, J. and F. Laube. 1999. Patterns of automobile dependence in cities: an international overview of key physical and economic dimensions with some implications for urban policy. Transportation Research Part A: Policy and Practice 33(7-8): 691-723.

Laakso, S. 1992. Public transport investment and residential property values in Helsinki. Scandinavian Housing and Planning Research 9(4): 217-229.

Landis, J., S. Guhathakurta, W. Huang, M. Zhang, and B. Fukuji. 1995. Rail Transit Investments, Real Estate Values, and Land Use Change: A Comparative Analysis of Five California Rail Transit Systems. Institute of Urban and Regional Development. University of California, Berkeley.

Levinson, H., S. Zimmerman, J. Clinger, S. Rutherford, R. L. Smith, J. Cracknell, and R. Soberman. 2009. TCRP 90, Bus Rapid Transit, Volume 1: Case Studies in Bus Rapid Transit.

Litman, T. 2013. Local Funding Options for Public Transportation. Victoria Transport Policy Institute.

McCarthy, P. 2001. Transportation Economics: Theory and Practice: A Case Study Approach Blackwell Publishing.

McIntosh, J., P. Newman, T. Crane, and M. Mouritz. 2011. Alternative Funding Mechanisms for Public Transport in Perth: the Potential Role of Value Capture. Committee for Perth. Downloaded from: http:// www.committeeforperth.com.au/images/stories/NewsMedia/Publications/16-Discussion\%20Paper-\%20Alternative $\% 20$ Funding\%20Mechanisms\%20for $\% 20$ Public $\% 20$ Transport $\% 20 \mathrm{in} \% 20$ Perth,\%202011.pdf.

McIntosh, J., P. Newman, J. Scheurer, and A. Wisdom. 2012. Initial Assessment of the Accessibility \& New Funding Opportunities for the Doncaster Rail Project, City of Manningham, Melbourne. Downloaded from http://www.manningham.vic.gov.au/council/consultation/on_track.html.

McIntosh J., P. Newman, and G. Glazebrook. 2013. Why fast train work: An assessment of a fast regional rail system in Perth, Australia. Journal of Transportation Technologies 3(2A): 37-47.

Mohammad, S., D. Graham, P. Melo, and R. Anderson. 2013. A meta-analysis of the impact of rail projects on land and property values. Transportation Research Part A 50: 158-170.

Mullins, J., E. Washington, and R. Stokes. 1990. Land use impacts of the Houston transitway system. Transportation Research Record 1237: 29-38.

Muth, R. 1969. Cities and Housing: The Spatial Pattern of Urban Residential Land Use. Chicago, IL: University of Chicago Press.

National Association of Realtors. 2013. The New Real Estate Mantra Location Near Public Transportation. Downloaded from http://www.apta.com/resources/statistics/Documents/NewRealEstateMantra.pdf.

National Council for Public-Private Partnerships. 2008. New York Avenue Metro Station. Downloaded from http://www.ncppp.org/cases/nystation.shtml.

Newman, P. and J. Kenworthy. 2011. Peak car use: understanding the demise of automobile dependence. World Transport Policy and Practice 17(2): 31-42.

Newman, P., G. Glazebrook, and J. Kenworthy. 2013. Peak car use and the rise of global rail: why this is happening and what it means for large and small cities. Journal of Transportation Technologies 3(4): 272-287.

NYC Department of Planning. 2013. Zoning Tools: Inclusionary Housing. http://www.nyc.gov/html/ $\mathrm{dcp} / \mathrm{html} /$ zone/zh_inclu_housing.shtml. 
PB. 2001. The Effect of Rail Transit on Property Values: A Summary of Studies. Report Neorail II Cleveland.

Perk, V. and M. Catala. 2009. Land Use Impacts of Bus Rapid Transit: Effects of BRT Station Proximity on Property Values Along the Pittsburgh Martin Luther King, Jr. East Busway. National Bus Rapid Transit Institute, University of South Florida.

PortlandStreetcar.http://www.portlandstreetcar.org/pdf/capital_and_operations_summary_20121115. pdf.

Pucher, J., N. Korattyswaroopam, and N. Ittyerah. 2004. The crisis of public transport in India: overwhelming needs but limited resources. Journal of Public Transportation 7: 95-113.

Punter, J. 2003. The Vancouver Achievement: Urban Planning and Design. UBC Press: Vancouver, BC.

Renne, J. and J. Wells. 2005. Transit-oriented development: Developing a strategy to measure success. NCHRP Research Results Digest 294.

Rodreguez, D. and F. Targa. 2004. Value of accessibility to Bogotás bus rapid transit system. Transport Reviews 24(5): 587-610.

Rybeck, W. 1981. Transit-induced land values: development and revenue implications. Economic Development Commentary (National Council for Urban Economic Development) 5(1): 23-27.

Rybeck, R. 2004. Using value capture to finance infrastructure and encourage compact development. Public Works Management \& Policy 8(4): 249-260.

Schneck and Diaz. 1999. Funding rail transit through tax increment financing. American Public Transit Association - Commuter Raill Rapid Transit Conference Proceedings: 78-87.

Sedway Group. 1999. Regional Impact Study. Report commissioned by Bay Area Rapid Transit District (BART).

Scheurer, J. 2010. Benchmarking Accessibility and Public Transport Network Performance in Copenhagen and Perth. Australasian Transport Research Forum, Canberra, Australia.

Smith, J. and T. Gihring, T. 2009. Financing Transit Systems Through Value Capture: An Annotated Bibliography. Victoria, British Columbia, Canada: Victoria Transport Policy Institute. Downloaded from: http://www.vtpi.org/smith.pdf.

Sherry, R. 1999. Property values and transportation facilities: finding the transportation land use connection. Journal of Planning Literature 13(4): 412-427.

Small, K. and E. T. Verhoef. 2007. The Economics of Urban Transportation. Routledge.

Sullivan, G., S. Johnson, and D. Soden. 2002. Tax Increment Financing (TIF) Best Practices Study. IPED Technical Reports. Paper 20.

Systematics, C. and KFH Group, McCollom Management Consulting, and B. Hemily. 2009. TCRP Report 129: Local and Regional Funding Mechanisms for Public Transportation.

US EPA. 2013. Infrastructure Financing Options for Transit-Oriented Development (Downloaded from: http://www.epa.gov/dced/pdf/2013-0122-TOD-infrastructure-financing-report.pdf).

Voith, R. 1993. Changing capitalization of CBD-oriented transportation systems: evidence from Philadelphia, 1970-1988. Journal of Urban Economics 33(3): 361-376.

Vuchic, V. 2005. Urban Transit. Operations, Planning and Economics. Hoboken, N.J.: John Wiley \& Sons.

Wacher, T. 1971. Public Transport and Land Use: A Strategy for London. The Institution.

Weinstein, B. and T. Clower. 1999. The initial economic impacts of the DART LRT system. Center for Economic Development and Research, University of North Texas.

- 2002. The impact of Dallas (Texas) area rapid transit light rail stations on taxable property valuations. Australasian Journal of Regional Studies 8(3): 389. 
Woodcock I., K. Dovey, S. Wollan, and I. Robertson. 2011. Speculation and resistance: constraints on compact city policy implementation in Melbourne. Urban Policy and Research 29(4): 343-362.

Yankaya, U. and H. Celik. 2004. Modelling the Impacts of Rail Transit Investment on the Values of Residential Property: A Hedonic Price Approach in the Case of Izmir Subway, Turkey. Report Izmir Institute of Technology, Department of Civil Engineering. Downloaded from: http://ecomod.net/sites/default/ files/document-conference/ecomod2006-rum/1368.pdf.

Yiu, C. and S. Wong. 2005. The effects of expected transport improvements on housing prices. Urban Studies 42(1): 113-125.

Zhao, Z. and K. Larson. 2011. Special assessments as a value capture strategy for public transit finance. Public Works Management Policy 16(4): 320-340.

Zhang, Q., X. Ye, and G. Chen. 2010. Low-carbon urban planning: a new vision. City Planning Review 34(2): 13-18. 